\title{
Д.
}

\section{Assessment of Daikin CA system}

Authors: Dr. L.J.S. Lukasse, M. Paillart MSc., G. Leentfaar, Ir. E.B. Wissink

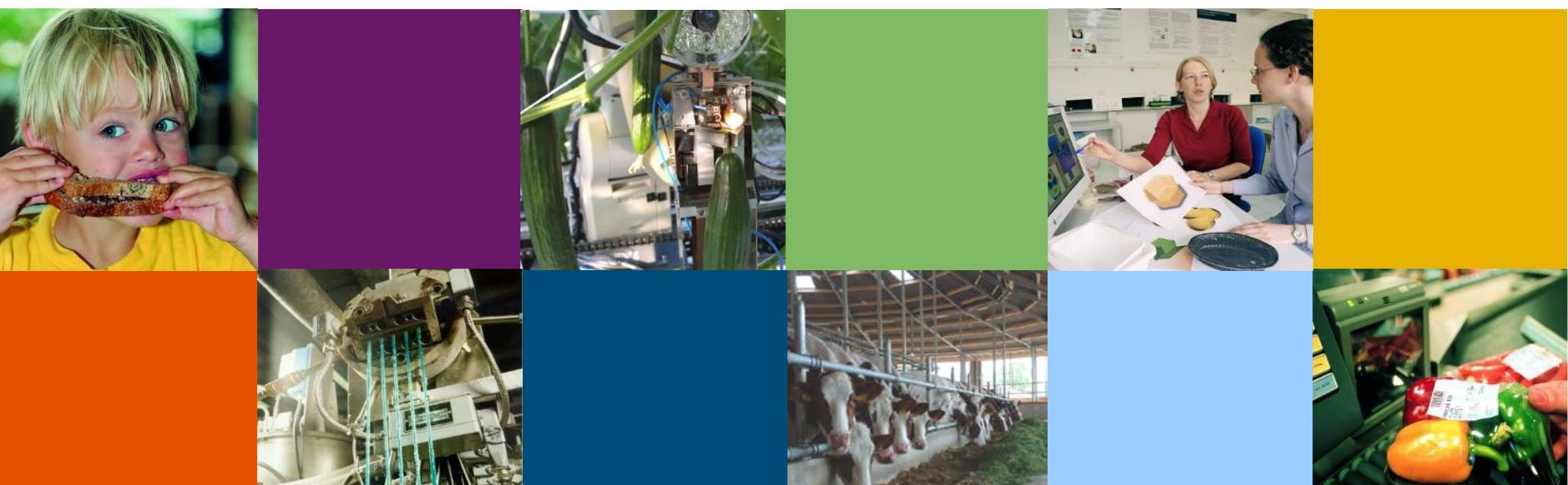




\section{Colophon}

Title Assessment of Daikin CA system

Author(s) Dr. L.J.S. Lukasse, M. Paillart MSc., G. Leentfaar, Ir. E.B. Wissink

Number 1791

Date of publication Febr. 2018

Version 0.0

Confidentiality $\quad$ Yes, till three years after date of publication

Project number $\quad 6239137700$

Approved by Dr. Nicole Koenderink

Review Internal

Name reviewer Ir. Eelke Westra

Sponsor Daikin Industries Ltd.

Client Daikin Industries Ltd.

Wageningen Food \& Biobased Research

P.O. Box 17

NL-6700 AA Wageningen

Tel: +31 (0)317480084

E-mail: info.fbr@wur.nl

Internet: www.wur.nl/foodandbiobased-research

(C) Wageningen Food \& Biobased Research, institute within the legal entity Stichting Wageningen Research All rights reserved. No part of this publication may be reproduced, stored in a retrieval system of any nature, or transmitted, in any form or by any means, electronic, mechanical, photocopying, recording or otherwise, without the prior permission of the publisher. The publisher does not accept any liability for inaccuracies in this report.

This report can be downloaded for free from February 2021 at https://doi.org/10.18174/563052/ or at www.wur.nl/wfbr (under publications). 


\section{Abstract}

The aim of this test report is to assess the performance of the Daikin vacuum pressure swing absorption (VPSA) based CA unit. To this end a series of climate chamber tests was done at temperatures ranging from -20 to $+50{ }^{\circ} \mathrm{C}$. All tests were done at $50 \mathrm{~Hz}$ power supply, assuming that capacities at $60 \mathrm{~Hz}$ can only be better. The following aspects were evaluated:

1. unit's air tightness.

2. lowest possible $\mathrm{O}_{2}$ concentration generated by the unit and flow rate at which this is done.

3. the unit's $\mathrm{CO}_{2}$ removal capacity.

In a representative test condition the system's $\mathrm{O}_{2}$ pulldown rate was compared to $\mathrm{O}_{2}$ pulldown rate in a passive CA system. The main purpose of CA is to reduce the produce respiration rate. Therefore the respiration rate of seven typical CA reefer cargos (apple, iceberg lettuce, blueberry, mango, banana, avocado and asparagus) was measured in both regular atmosphere and controlled atmosphere.

The main conclusions are:

1. The unit's air tightness amply surpasses the ISO1496-2 standard.

2. At ambient temperatures above $+10{ }^{\circ} \mathrm{C}$ the $\mathrm{CA}$ system is able to generate approx. 16 $\mathrm{L} / \mathrm{min}$ of air with approx. $5 \% \mathrm{O}_{2}$. At lower ambient temperature the $\mathrm{O}_{2}$ concentration increases.

3. It is to be expected that in shipments with low $\mathrm{CO}_{2}$ set point in cold ambient air the unit will struggle to avoid too high $\mathrm{CO}_{2}$. This is because the $\mathrm{CO}_{2}$ removal capacity is limited, and the control logic erroneously prioritizes maintaining $\mathrm{O}_{2}$ over avoiding too high $\mathrm{CO}_{2}$.

4. The tested CA conditions largely reduce the respiration rate of the tested fruits and vegetables, esp. avocado, green asparagus, banana and mango respond well to the tested CA conditions.

The main recommendations are:

1. Revise the CA unit's control logic. Involve WFBR in improving the control specifications, and later on in testing to verify the correct implementation.

2. Change the control logic such that prolonged periods with $\mathrm{CO}_{2}>\mathrm{CO}_{2, \text { set }}$ Or $\mathrm{O}_{2}<\mathrm{O}_{2 \text {,set }}$ are avoided.

3. Mind the gas sensor accuracy, and verifying the accuracies in PTI (CA-tests). 


\section{Content}

$\begin{array}{ll}\text { Abstract } & 3\end{array}$

1 Introduction $\quad 6$

2 Theory 7

3 Description of test equipment 9

4 Methods $\quad 10$

$\begin{array}{lll}4.1 & \text { Test 1: air leakage } & 10\end{array}$

4.2 Test 2: generated nitrogen supply rate and purity 10

4.3 Test 3: $\mathrm{CO}_{2}$ removal capacity 11

4.4 Test 4: pulldown rate of $\mathrm{O}_{2}$ concentration in active and passive systems 12

4.5 Test 5: Effect of CA on respiration rate 14

4.6 Model calculations: effects of over pressure and moisture injection 18

5 Results 19

5.1 Test 1: air leakage 19

5.2 Test 2: generated nitrogen supply rate and purity 19

5.3 Test 3: $\mathrm{CO}_{2}$ removal capacity 19

5.4 Test 4: pulldown rate of $\mathrm{O}_{2}$ concentration in active and passive systems 21

$\begin{array}{lll}\text { 5.4.1 sensor accuracy } & 21\end{array}$

5.5 Test 5: Effect of CA on respiration rate 23

5.6 Model calculations: effects of over pressure and moisture injection 23

$\begin{array}{ll}\text { 5.6.1 water vapour injection } 23 & 23\end{array}$

5.6.2 effect of over pressure on the ingress of ambient air 24

6 Discussion 25

6.1 Test 1: air leakage 25

6.2 Test 2: generated nitrogen supply rate and purity 25

6.3 Test 3: $\mathrm{CO}_{2}$ removal capacity 25

6.4 Test 4: pulldown rate of $\mathrm{O}_{2}$ concentration in active and passive systems 28

$\begin{array}{lll}\text { 6.4.1 sensor accuracy } & 29\end{array}$

6.5 Test 5: Effect of CA on respiration rate 30

6.6 Model calculations: effects of over pressure and water vapour injection 30

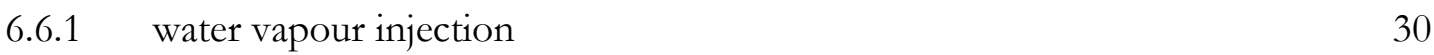

6.6.2 effect of over pressure on the ingress of ambient air 31

7 Conclusions $\quad 32$

8 Recommendations 33

References

$\begin{array}{ll}\text { Acknowledgements } & 35\end{array}$ 
Appendix 1, nomenclature

Appendix 2, test log 


\section{Introduction}

Since 2017 Daikin is bringing its new CA unit to the market. Wageningen Food \& Biobased Research (WFBR) is renown in the reefer industry as one of the world's leading independent post-harvest research institutes, with a well-equipped reefer test facility. Therefore Daikin has asked WFBR to test its CA unit and the unit's effect on respiration rate for seven typical fruits carried under CA.

Aim of this report is to assess the performance of the Daikin vacuum pressure swing absorption (VPSA) based CA unit. The next section explains how this is done. 


\section{Theory}

CA (Controlled Atmosphere) units are meant to control the $\mathrm{O}_{2}$ and $\mathrm{CO}_{2}$ concentration in a reefer container. The mass balances for $\mathrm{O}_{2}$ and $\mathrm{CO}_{2}$ in a container are given by

$$
\begin{aligned}
& V_{\text {air }} \times 1000 \times \frac{d O_{2}}{d t}=\phi_{v p s a} \times 60 \times\left(O_{2, v p s a}-O_{2}\right)+\phi_{\text {ext }} \times 60 \times\left(O_{2, \text { ext }}-O_{2}\right)- \\
& m_{\text {prod }} \times r_{C O 2} \times 100 \\
& {\left[\mathrm{cL} \mathrm{h}^{-1}\right]} \\
& V_{\text {air }} \times 1000 \times \frac{d \mathrm{CO}_{2}}{d t}=\phi_{v p s a} \times 60 \times\left(\mathrm{CO}_{2, v p s a}-\mathrm{CO}_{2}\right)+\phi_{\text {ext }} \times 60 \times \\
& \left(\mathrm{CO}_{2, \text { ext }}-\mathrm{CO}_{2}\right)+m_{\text {prod }} \times r_{\mathrm{CO} 2} \times 100 \\
& {\left[\mathrm{cL} \mathrm{h}^{-1}\right]}
\end{aligned}
$$

See the appendix on p. 36 for this report's nomenclature.

Assumptions made in the equations above:

1. Accumulation of $\mathrm{O}_{2}$ and $\mathrm{CO}_{2}$ in the fruit's tissue is negligible.

2. Fresh air exchange is closed (as always in CA transports).

3. Air leakage rate is zero.

4. $\mathrm{r}_{\mathrm{CO} 2}$ Is not affected by $\mathrm{O}_{2}$ and $\mathrm{CO}_{2}$, an assumption which simplifies the math, but is in fact not valid in situations where $\mathrm{O}_{2}$ and $\mathrm{CO}_{2}$ deviate significantly from RA (Regular Atmosphere) conditions.

In this report the terms 'active system' and 'passive system' are used. In the industry there sometimes is discussion about what is active and what is passive. The definitions used in this report are:

1. Passive system $=$ a CA system without any means to actively manipulate $\mathrm{O}_{2}$ or $\mathrm{CO}_{2}$, where product respiration ( $\mathrm{m}_{\text {prod }} \times \mathrm{r}_{\mathrm{CO} 2} \times 100$ in eqn. 1 and 2 ) is the only means to reduce $\mathrm{O}_{2}$ and increase $\mathrm{CO}_{2}$ in the container.

2. Active system $=$ any $C A$ system where the unit is equipped with a device to supply a flow of air with low $\mathrm{O}_{2}$ concentration to the container $\left(\phi_{v p s a} \times 60 \times\left(O_{2, v p s a}-O_{2}\right)\right.$ in eqn. 1).

The performance of the Daikin CA unit is assessed in multiple climate chamber tests. If the container is insufficiently air tight then an external supply flow rate $\phi_{\text {ext }}$ continues to exist in which $\mathrm{O}_{2, \text { ext }}=21 \%$ and $\mathrm{CO}_{2, \mathrm{ext}}=0 \%$. Therefore the air tightness of container box + unit is tested (section 4.1). The unit's VPSA system draws in ambient air, separates its different components, and supplies a modified gas mixture with reduced $\mathrm{O}_{2}$ concentration $\mathrm{O}_{2, \mathrm{vpsa}}$ to the container at a flow rate $\phi_{\text {vpsa. }}$. Of course $\mathrm{O}_{2, \text { vpsa }}$ and $\phi_{\text {vpsa }}$ are important characteristics of the unit. Therefore the lowest possible $\mathrm{O}_{2, \mathrm{vpsa}}$ and accompanying $\phi_{\mathrm{vpsa}}$ are assessed. Section 4.2 describes how this is done. The CA unit cannot actively remove $\mathrm{CO}_{2}$, but has to do this by manipulating its $\mathrm{O}_{2, \mathrm{vpsa}}$ and $\phi_{\mathrm{vpsa}}$. Section 4.3 describes how the $\mathrm{CO}_{2}$ removal capacity is measured. The rate of $\mathrm{O}_{2}$ pulldown is another important characteristic. It is the result of hardware capacity, control, and cargo. Of course it is interesting to observe this pulldown rate, and to see how it compares to the rate of pulldown in case of passive CA systems. This is covered in section 4.4. Finally the main purpose of $\mathrm{CA}$ is to reduce the produce respiration rate $\mathrm{r}_{\mathrm{CO} 2}$. Therefore the respiration rate of seven typical CA reefer cargos is measured in both RA and CA (section 4.5). Finally the questions 
remain how the supply of treated air ( $\left.\phi_{\text {vpsa }}\right)$ affect air leakage into the container, and the container's moisture balance. These questions are addressed in section 4.6.

Section 5 reports the results, which are then discussed in section 6 . The division in subsections in section 5 and section 6 is identical to the division used in section 4. Finally conclusions are drawn in section 7 , and recommendations are given in section 8 . 


\section{Description of test equipment}

A Daikin CA unit has been installed on a reefer container and tested in a climate chamber at WFBR. Table 1 lists the characteristics of the tested container equipment.

Power supply during all tests: $50 \mathrm{~Hz} / 400 \mathrm{~V}$. The reason to test at $50 \mathrm{~Hz}$ instead of $60 \mathrm{~Hz}$ is that this is a worst case situation. It is safe to assume that performance at $60 \mathrm{~Hz}$ can only be better.

Table 1, characteristics of tested refrigeration unit / CA unit / container.

\begin{tabular}{|l|l|}
\hline Description of characteristic & Value \\
\hline Container type & $40 \mathrm{ft} . \mathrm{HC}$ \\
\hline Container ID & MEGU000201[2] \\
\hline Refrigeration unit type & LX10F11B3, Daikin Zestia \\
\hline Refrigeration unit mng. no. & M000003 \\
\hline Refr. unit man. date & $05 / 2017$ \\
\hline Refr. unit software version & $30 \mathrm{E} 4$ \\
\hline CA unit mfg. no. & $1-17050218$ \\
\hline CA unit type & Type 1, LXCA 04-5-2 \\
\hline CA unit software version & 40 \\
\hline Controller model & DECOS Va \\
\hline Controller S/N & RC9550018524 \\
\hline
\end{tabular}

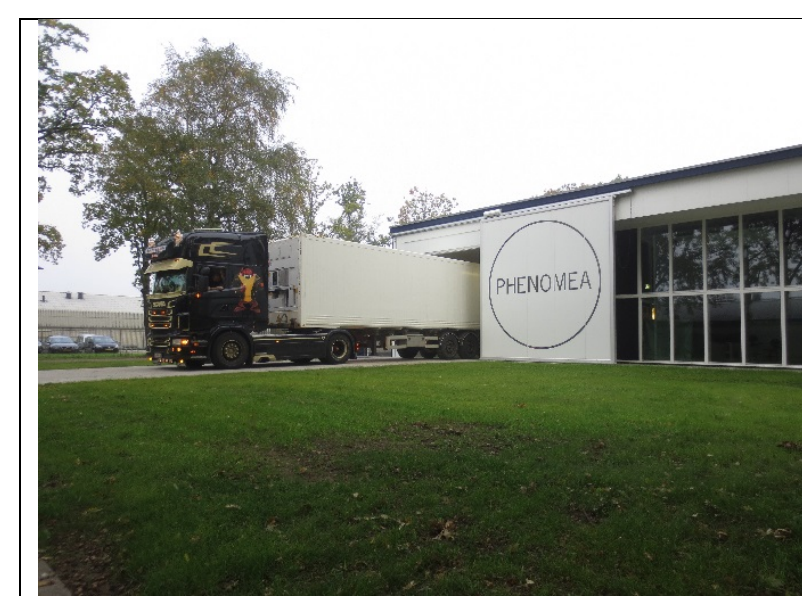

Fig. 1, container enters chamber.

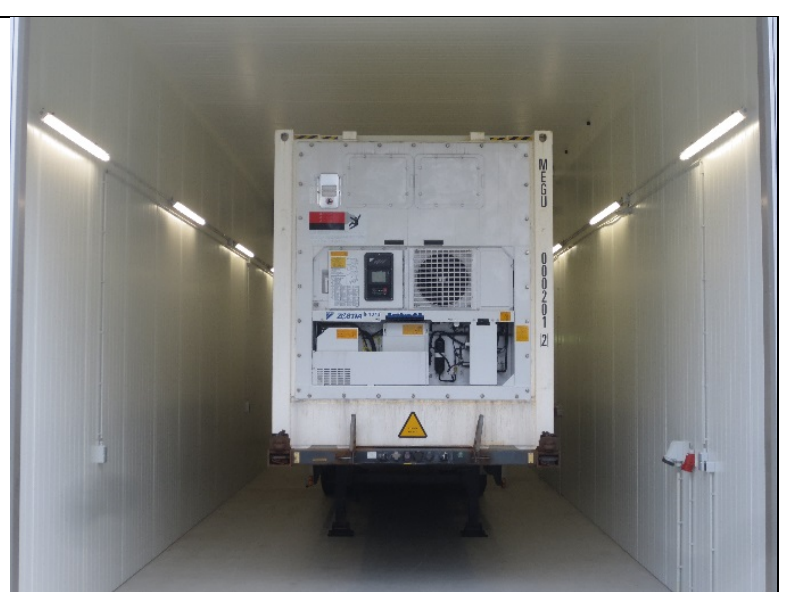

Fig. 2, container in test chamber. 


\section{Methods}

During all tests the unit's data log interval is set to 15 minutes, its lowest possible value.

\subsection{Test 1: air leakage}

The air leakage rate of the test container has been measured with and without CA curtain at the door-end. The container lacked a curtain rail. Therefore the CA curtain was clasped between door gasket and frame. On request of Daikin the used test protocol was the so-called pressure decay method as specified in ISO1496-2. The specification is to raise the internal pressure to just above $490 \mathrm{~Pa}$ ( 2 inch water column) and record the time needed for the pressure to drop from 490 to $245 \mathrm{~Pa}$ (1 inch water column).

During the test the drain holes were plugged, the vent opening was closed, and the container was pressurized by connecting the exhaust of a centrifugal fan to the unit's drain line.

\subsection{Test 2: generated nitrogen supply rate and purity}

The Daikin VPSA system generates nitrogen of a certain purity $\mathrm{O}_{2, \text { vpsa }}$ at a certain flow rate $\phi_{\text {vpsa }}$ and supplies it into the container. The system operates in cycles of generation and regeneration. Under the installed software the system has four possible operating modes with different levels of nitrogen purity. See Table 2 for the specifications received from Daikin upfront. The higher the nitrogen purity the lower the average flow rate. Only for the operating mode with the highest nitrogen purity the system's supply flow rate was tested, and the $\mathrm{O}_{2}$ concentration in the flow was assessed. This test was done at a whole series of ambient temperatures $\left(\mathrm{T}_{\mathrm{amb}}\right):-20^{\circ} \mathrm{C},-10{ }^{\circ} \mathrm{C}, 0$ ${ }^{\circ} \mathrm{C},+8{ }^{\circ} \mathrm{C},+18{ }^{\circ} \mathrm{C},+28{ }^{\circ} \mathrm{C},+38^{\circ} \mathrm{C}$ and $+50^{\circ} \mathrm{C}$.

Table 2, possible operation modes of Daikin VPSA system.

\begin{tabular}{|l|r|r|}
\hline Mode & flow rate [L/min] & $\mathbf{O}_{2}[\%]$ \\
\hline Respiration & 0 & N/A \\
\hline $5 \%$ & 10 & 5 \\
\hline $8 \%$ & 19.5 & 8 \\
\hline ventilation & 39 & 20.8 \\
\hline
\end{tabular}

It is a feature of the Daikin system that as long as the container's internal atmosphere is \pm RA it operates in 5\%-mode. In the test the nitrogen supply tube was extended with a 2 meters long tube with larger diameter. A water basin (black in Fig. 3) was placed inside the container at the unit-end. A 35 L bucket (white in Fig. 3) was submerged upside down in the basin. The nitrogen supply tube was put underneath the bucket. The measurement continued till the bucket was nearly filled. It was ensured that the sampling covered complete operation cycles of the CA unit. With a stopwatch the required time was recorded. Afterwards the volume of the gas captured under the bucket was measured. The flow rate was then calculated by dividing volume by recorded time. The $\mathrm{O}_{2}$ concentration of the captured gas was measured with a gas analyser (Dansensor Checkmate 2, Mocon Dansensor, Denmark). 


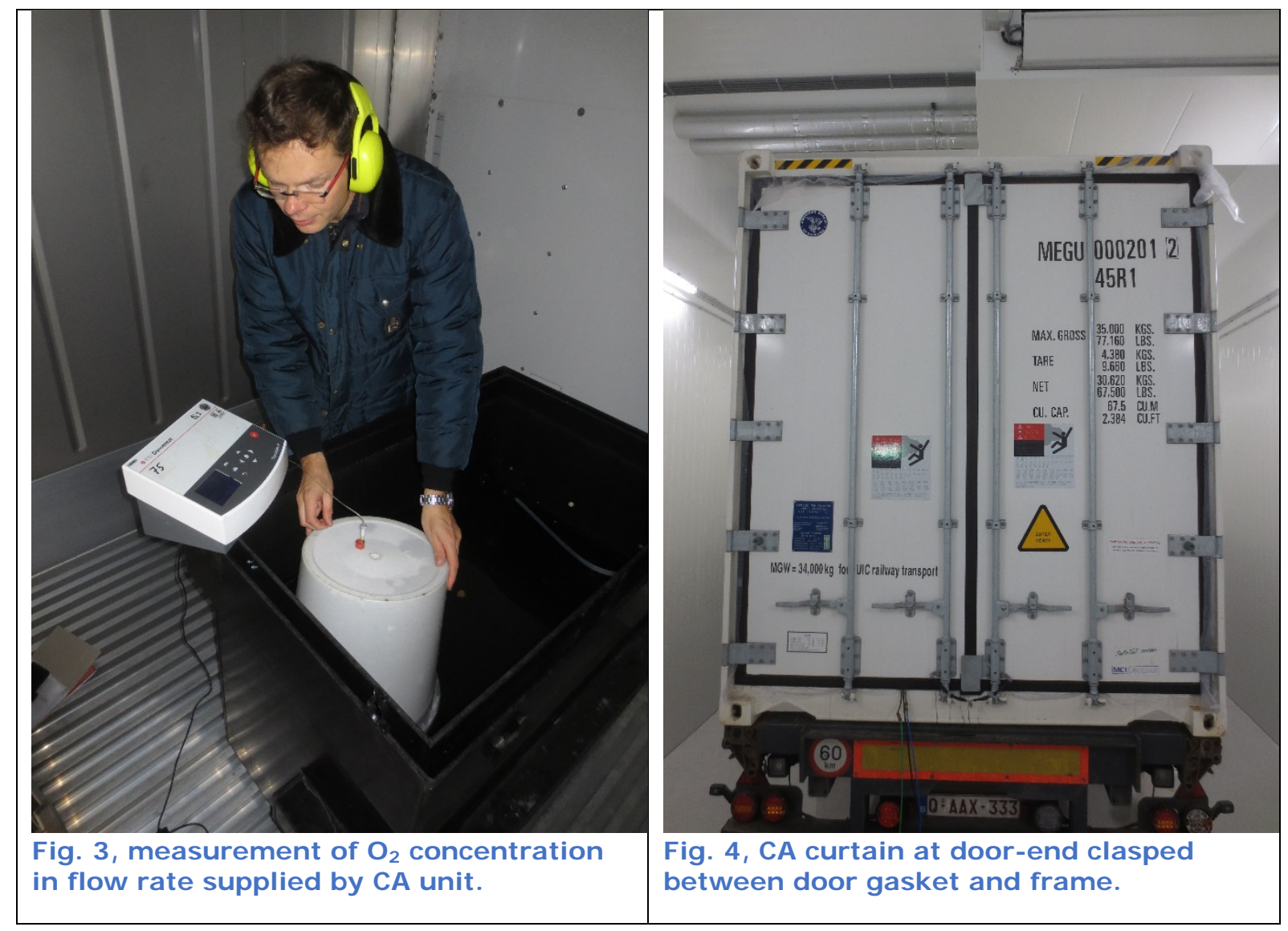

\subsection{Test 3: $\mathrm{CO}_{2}$ removal capacity}

The $\mathrm{CO}_{2}$ removal capacity was assessed at Tset $=6{ }^{\circ} \mathrm{C}, \mathrm{O}_{2, \text { set }}=5 \%$ and $\mathrm{CO}_{2, \text { set }}=3 \%$, according to Daikin a test condition representative for avocado shipment. In preparation of this test the system was brought in the desired steady state. The approach during the test was to simulate respiration by supplying an external gas mixture of $0 \% \mathrm{O}_{2}, 8 \% \mathrm{CO}_{2}, 92 \% \mathrm{~N}_{2}$ into the container, and gradually increase the flow rate $\phi_{\text {ext }}$ to assess at which flow rate the desired $\mathrm{O}_{2} / \mathrm{CO}_{2}$ conditions could no longer be maintained. The mixture was chosen such that it elevates $\mathrm{CO}_{2}$ as much as it depresses $\mathrm{O}_{2}$, like respiration does. This test was done at two ambient temperatures: $20{ }^{\circ} \mathrm{C}$ and $+50{ }^{\circ} \mathrm{C}$. To speed up the dynamics of $\mathrm{O}_{2}$ and $\mathrm{CO}_{2}$ in the container, the container was filled as much as possible with big balloons (CA store air lungs) to reduce the free air volume $\mathrm{V}_{\text {air }}$, see Fig. 5 and Fig. 6. During the test the CA curtain at door-end was clasped between door gasket and frame (Fig. 4). 


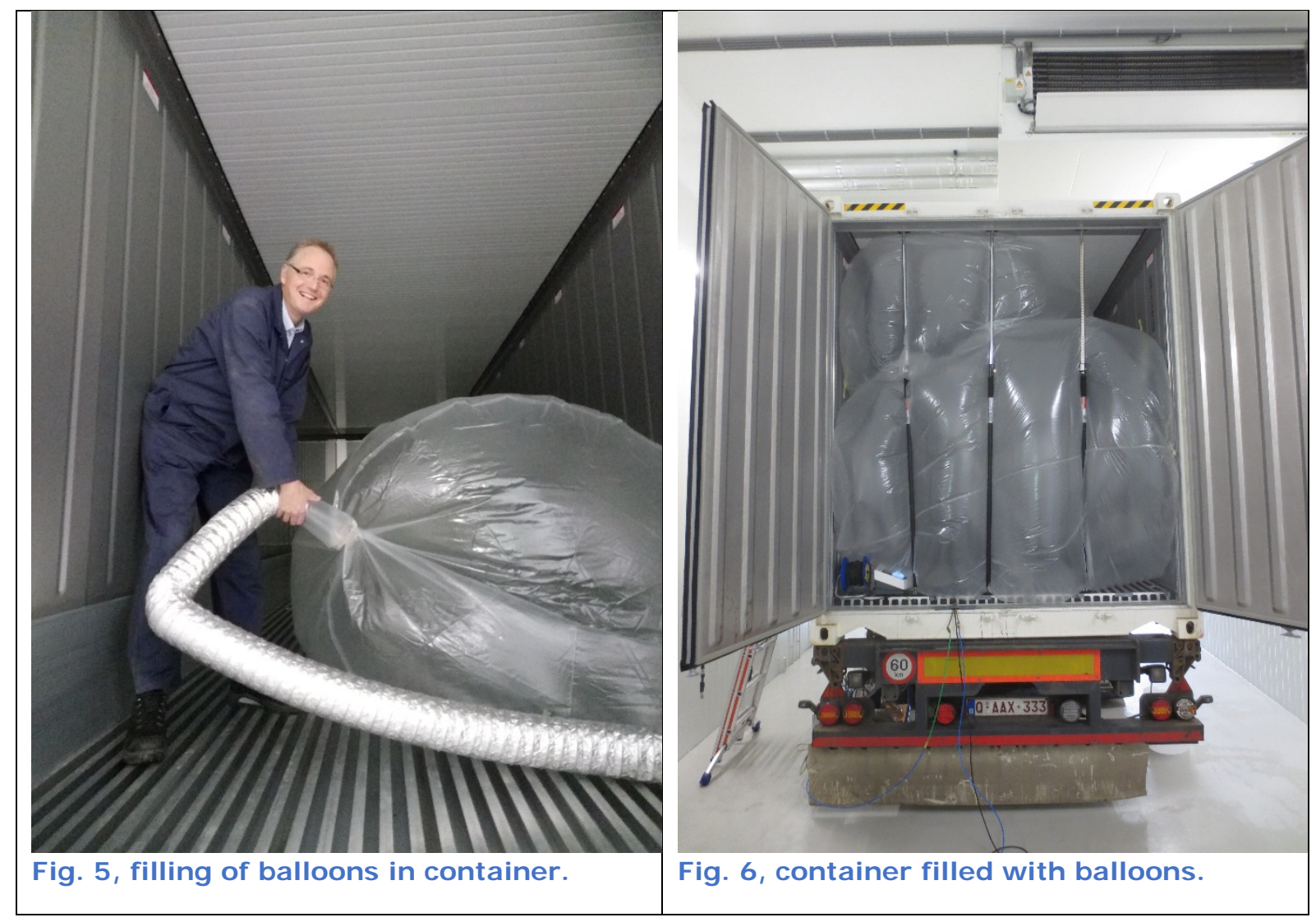

\subsection{Test 4: pulldown rate of $\mathrm{O}_{2}$ concentration in active and passive systems}

The difference in rate of $\mathrm{O}_{2}$ pulldown of active $\mathrm{CA}$ as compared to passive CA is assessed by doing a pulldown twice: once with the $\mathrm{CA}$ unit on, and once with the CA unit off. During both tests $\mathrm{T}_{\text {set }}=14{ }^{\circ} \mathrm{C}, \mathrm{O}_{2 \text {,set }}=3 \%, \mathrm{CO}_{2, \text { set }}=5 \%$, and a gas mixture of $0 \% \mathrm{O}_{2}, 21 \% \mathrm{CO}_{2}$, and $79 \% \mathrm{~N}_{2}$ is supplied at a constant flow rate. During the test $\mathrm{T}_{\text {amb }}=38^{\circ} \mathrm{C}$. In- and outside temperatures were stabilized for 15 hours before the pulldown tests were started. Air leakage rate during this test was such that pressure decay from 2 inch to 1 inch took at least 4 minutes, as the CA curtain was clasped between door and frame (Fig. 4).

The external supply flow rate $\phi_{\text {ext }}$ was set at a level such that at the start of the test, when the container atmosphere is RA (Regular Atmosphere), the effect equals the effect of a load of 18 tonnes of bananas with a respiration rate $3.9 \mathrm{~L}$.tonne $\mathrm{e}^{-1} \cdot \mathrm{h}^{-1}$, being the average of $\mathrm{O}_{2}$ consumption and $\mathrm{CO}_{2}$ production measured in RA (Table 10). The flow rate equivalent of $18 \times 3.9 \mathrm{~L} / \mathrm{h}$ respiratory $\mathrm{CO}_{2}$ production follows from:

$$
\phi_{\text {ext }} \times 60 \times\left(\mathrm{CO}_{2, \text { ext }}-\mathrm{CO}_{2, \text { ini }}\right)=18 \times 3.9 \times 100
$$

Solving above equation for $\phi_{\text {ext }}$ yields

$$
\phi_{\text {ext }}=\frac{18 \times 3.9 \times 100}{60 \times\left(\mathrm{CO}_{2, \text { ext }}-\mathrm{CO}_{2, \text { ini }}\right)}=\frac{18 \times 3.9 \times 100}{60 \times(21-0)}=5.6 \quad\left[\mathrm{~L} \mathrm{~min}^{-1}\right]
$$


Hence, the gas flow supplied ( $\left.\phi_{\text {ext }}\right)$ in both the passive and active tests is $5.6 \mathrm{~L} / \mathrm{min}$ of a mixture with $21 \% \mathrm{CO}_{2}$ and $79 \% \mathrm{~N}_{2}$.

In pulldown $\mathrm{V}_{\text {air }}$ in equations 1 and 2 matters. In an empty $40 \mathrm{ft} \mathrm{HC}$ container $\mathrm{V}_{\text {air }}=\mathrm{L} \mathrm{x} \mathrm{B} \mathrm{x} \mathrm{H}=$ $11.59 \times 2.29 \times 2.55=68 \mathrm{~m}^{3}$. In a container fully stuffed with \pm 18 tonnes of fruit the remaining free air volume is less. Bananas with a mass density of approx. $950 \mathrm{~kg} / \mathrm{m}^{3}$ occupy $\mathrm{m}_{\text {prod }} / \rho_{\text {prod }}=$ $18,000 / 950=19 \mathrm{~m}^{3}$. Also packaging materials occupy some space. In the test that is simulated by occupying approx. $30 \mathrm{~m}^{3}$ of the container's interior with three \pm maximally filled CA lungs of $10 \mathrm{~m}^{3}$ each (Fig. 7).

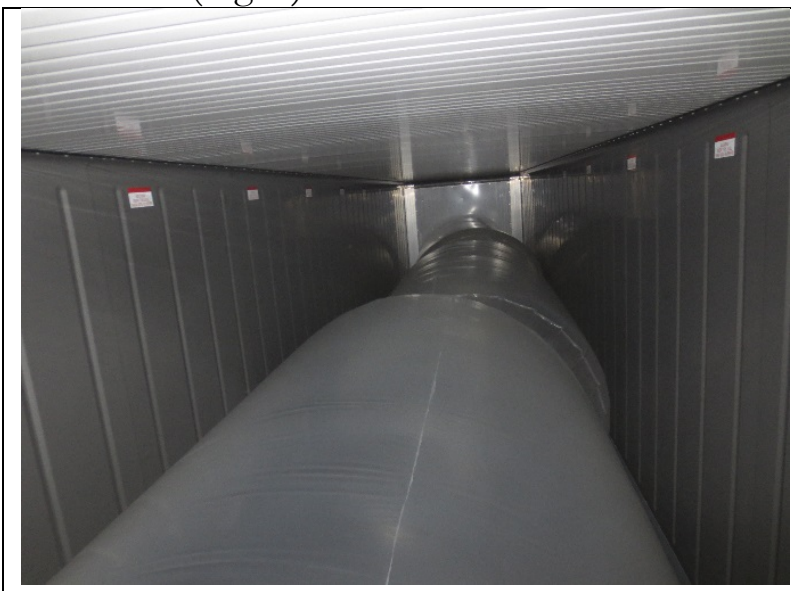

Fig. 7, three balloons of $10 \mathrm{~m}^{3}$ each.

It was noted on beforehand that these test results could deviate from the pulldown situation in a real load of bananas for multiple reasons. On the other hand there was no indication that another test would be more realistic. Table 3 lists multiple reasons why this test deviates from the real situation. It is felt that especially the decrease of respiration rate, mentioned in Table 3 , may be a big factor. But the factor is unknown, how the test differs from the real situation is unknown, and the effect will be the same in both tests.

Table 3, $\mathrm{O}_{2}$ pulldown test: how test deviates from real.

\begin{tabular}{|l|l|}
\hline How test deviates from real & consequence \\
\hline Air volume smaller or larger than real. & Faster or slower pulldown \\
\hline No fruit tissue to accumulate $\mathrm{CO}_{2} / \mathrm{O}_{2}$ in. & Faster pulldown \\
\hline $\begin{array}{l}\text { In reality during pulldown the internal temperature decreases. In } \\
\text { the test there's a constant internal temperature. }\end{array}$ & $\begin{array}{l}\text { Unknown. At least the test } \\
\text { condition is clearly } \\
\text { described and } \\
\text { reproducible. }\end{array}$ \\
\hline $\begin{array}{l}\text { In reality during pulldown respiration decreases in an unknown } \\
\text { way due to decreasing temperature and } \mathrm{O}_{2} \text {, and increasing } \mathrm{CO}_{2} . \\
\begin{array}{l}\text { In the test there's a constant supply of low } \mathrm{O}_{2} \text { and high } \mathrm{CO}_{2}, \\
\text { effectively resulting in a decreasing simulated respiration rate. }\end{array}\end{array}$ & $\begin{array}{l}\text { Unknown, but at least } \\
\text { respiration gradually } \\
\text { decreases in both cases. }\end{array}$ \\
\hline
\end{tabular}


Prior to testing four simulations were ran: passive and active system, both in the test situation and in case of a real load. These simulations indicated that the above described test procedure was an acceptable compromise between the wishes to test realistically and practically feasible.

\subsection{Test 5: Effect of CA on respiration rate}

CA reduces respiration rate to extend storage life. To get a feeling for the effect of CA on respiration rate, it was measured for seven different products (Table 4), both in RA and in the CA conditions specified below. The test products, temperatures and CA conditions were requested by Daikin.

Table 4, products of which respiration rate is measured, and the test conditions.

\begin{tabular}{|l|l|l|}
\hline product & temperature & CA condition \\
\hline Apple & $0.5^{\circ} \mathrm{C}$ & $2 \% \mathrm{O}_{2}, 2 \% \mathrm{CO}_{2}$ \\
\hline Iceberg lettuce & $0.5^{\circ} \mathrm{C}$ & $5 \% \mathrm{O}_{2}, 1 \% \mathrm{CO}_{2}$ \\
\hline Blueberry & $0.5{ }^{\circ} \mathrm{C}$ & $5 \% \mathrm{O}_{2}, 15 \% \mathrm{CO}_{2}$ \\
\hline Mango & $10^{\circ} \mathrm{C}$ & $5 \% \mathrm{O}_{2}, 5 \% \mathrm{CO}_{2}$ \\
\hline Banana & $14{ }^{\circ} \mathrm{C}$ & $3 \% \mathrm{O}_{2}, 5 \% \mathrm{CO}_{2}$ \\
\hline Avocado & $6{ }^{\circ} \mathrm{C}$ & $2 \% \mathrm{O}_{2}, 2 \% \mathrm{CO}_{2}$ \\
\hline Asparagus & $0.5^{\circ} \mathrm{C}$ & $5 \% \mathrm{O}_{2}, 10 \% \mathrm{CO}_{2}$ \\
\hline
\end{tabular}

Products were purchased at importer or at local grocery shop according to their required maturity stadium. Table 5 summarizes specifications for each product.

Table 5, Products specifications used for the respiration rate measurements.

\begin{tabular}{|c|c|c|c|c|}
\hline Product & Supplier & Cultivar & Origin & Remarks \\
\hline Banana & Chiquita & Cavendish & Panama & $\begin{array}{l}\text { Transport within LDPE foil with } \\
\text { macro-perforation }\end{array}$ \\
\hline Avocado & $\begin{array}{l}\text { Bakker } \\
\text { Barendrecht }\end{array}$ & Hass & Chile & \\
\hline Mango & $\begin{array}{l}\text { Bakker } \\
\text { Barendrecht }\end{array}$ & Keitt & Israel & \\
\hline $\begin{array}{l}\text { Iceberg } \\
\text { lettuce }\end{array}$ & $\begin{array}{l}\text { Local grocery } \\
\text { shop }\end{array}$ & Unknown & $\begin{array}{l}\text { The } \\
\text { Netherlands }\end{array}$ & $\begin{array}{l}\text { Packed within LDPE foil, packaging } \\
\text { removed before starting respiration test }\end{array}$ \\
\hline Apple & Van Kessel & \begin{tabular}{|l|l|} 
Cox \\
Orange
\end{tabular} & $\begin{array}{l}\text { The } \\
\text { Netherlands }\end{array}$ & \\
\hline Blueberry & $\begin{array}{l}\text { Local grocery } \\
\text { shop }\end{array}$ & Unknown & Poland & $\begin{array}{l}\text { Packed in trays of } 125 \text { gram, packaging } \\
\text { removed before starting respiration test }\end{array}$ \\
\hline Asparagus & $\begin{array}{l}\text { Local grocery } \\
\text { shop }\end{array}$ & Unknown & Spain & $\begin{array}{l}\text { Green asparagus packed per bunch of } \\
500 \text { gram }\end{array}$ \\
\hline
\end{tabular}


Measurements were done in triplicates. On day of purchase, products were randomly placed in containers. For blueberries and asparagus 2 litre containers were used, for the other products 70 $\mathrm{L}$ containers. The weight of the product was recorded. The containers were then flushed with the humidified CA or the RA gases at a flow of $500 \mathrm{ml} / \mathrm{min}$ or $250 \mathrm{~mL} / \mathrm{min}$ for the 70 litres or 2 litres containers respectively. The first respiration rate measurement was performed 48-72 hours after starting flushing the containers. This long adaptation period gives enough time for the product to adapt to its new storage conditions.

A gas analyser (Dansensor Checkmate 2, Mocon Dansensor, Denmark) was used to monitor the oxygen and carbon dioxide content inside the containers at the beginning and at the end of the accumulation period. The accumulation period depended on the activity of the product. The accumulation period was stopped when the $\mathrm{CO}_{2}$ content increased at least $1 \%$ (absolute value). After the first respiration measurement, the containers were reconnected to the gas supply for at least 48 hours before starting the second respiration rate measurement.

For each product and gas condition three containers were used. Prior the respiration rate test, the Dansensor was calibrated by measuring 3 calibration gas mixes (data not shown).

At the end of the tests, products were removed and the density of the products was measured on selected samples. The density of the product was calculated using the ratio between the weight under water and the 'dry' weight. Product density was used to determine the volume of the product inside the container/cuvette and so deduce the free air volume in the container.

Oxygen consumption and carbon dioxide production are expressed in $\mathrm{mL}$ gas per kilogram product per hour and calculated from

$$
r_{\mathrm{CO} 2, \text { prod }}=\frac{\left(\mathrm{CO}_{2}\left(t_{\text {end }}\right)-\mathrm{CO}_{2}\left(t_{\text {start }}\right)\right) * V_{\text {air }} * 10}{\left(t_{\text {end }}-t_{\text {start }}\right) * m_{\text {prod }}} \quad\left[\mathrm{mL} \cdot \mathrm{kg}^{-1} \cdot \mathrm{h}^{-1}\right]
$$

With $\mathrm{CO}_{2}$ the carbon dioxide concentration in $\%, \mathrm{~V}_{\text {air }}$ the free air volume in $\mathrm{L}, \mathrm{m}_{\text {prod }}$ the amount of produce in $\mathrm{kg}$, and time $(\mathrm{t})$ measured in hours. 


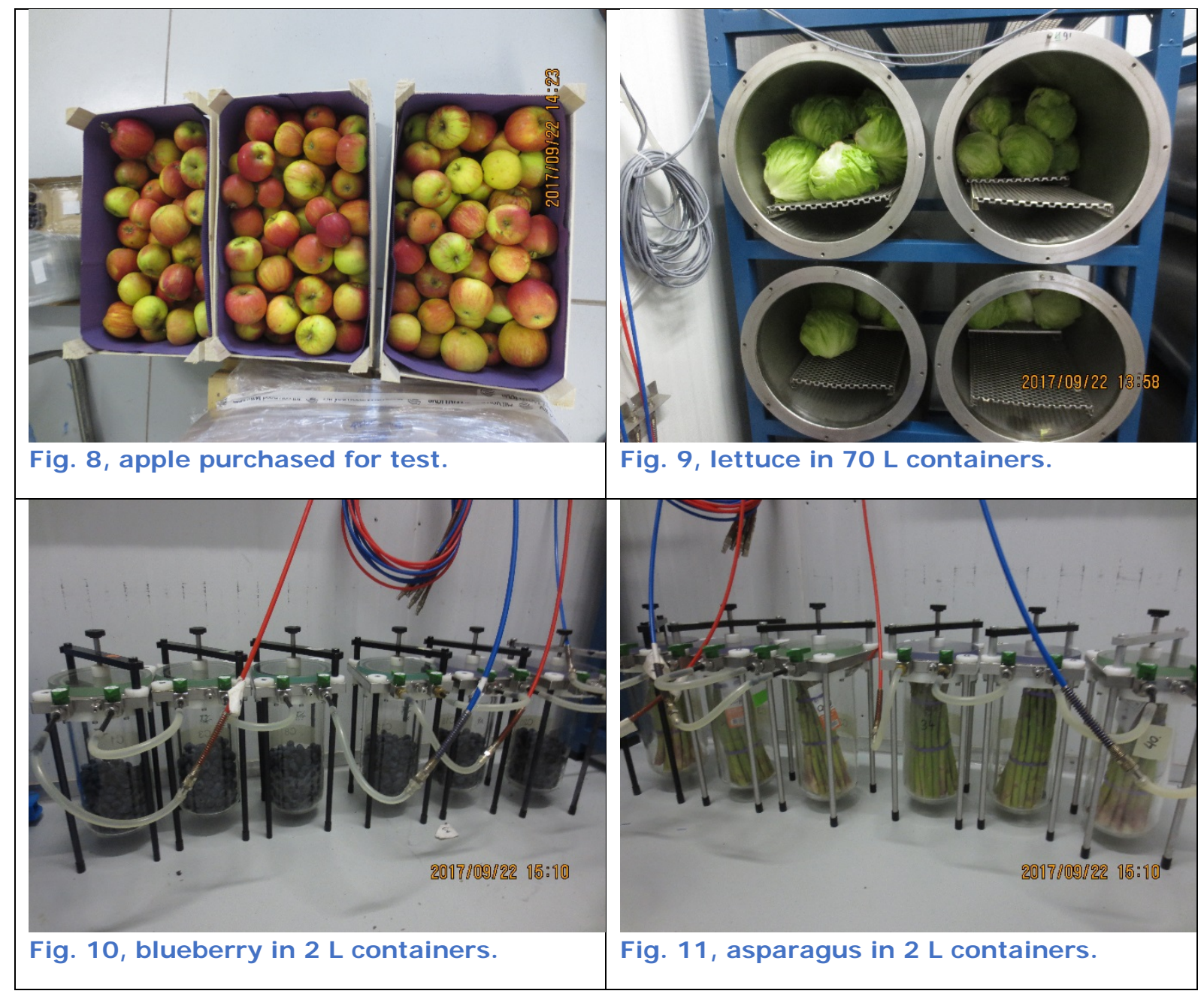




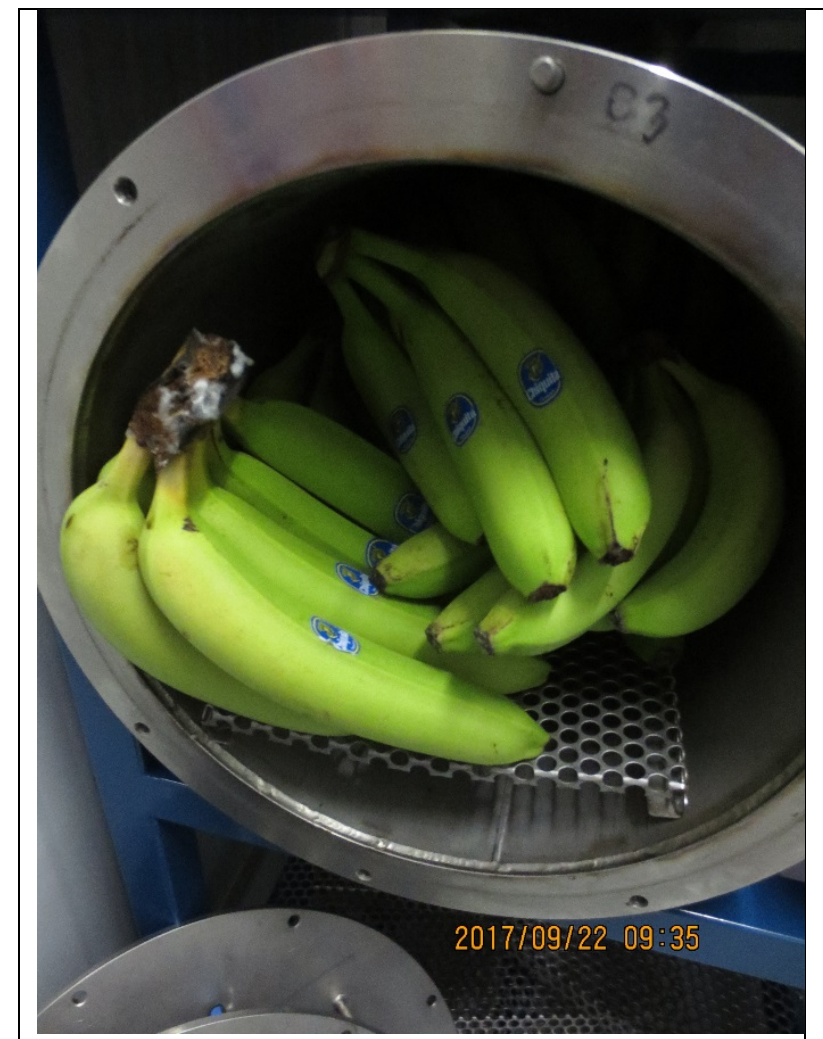

Fig. 12, banana in 70 L container.

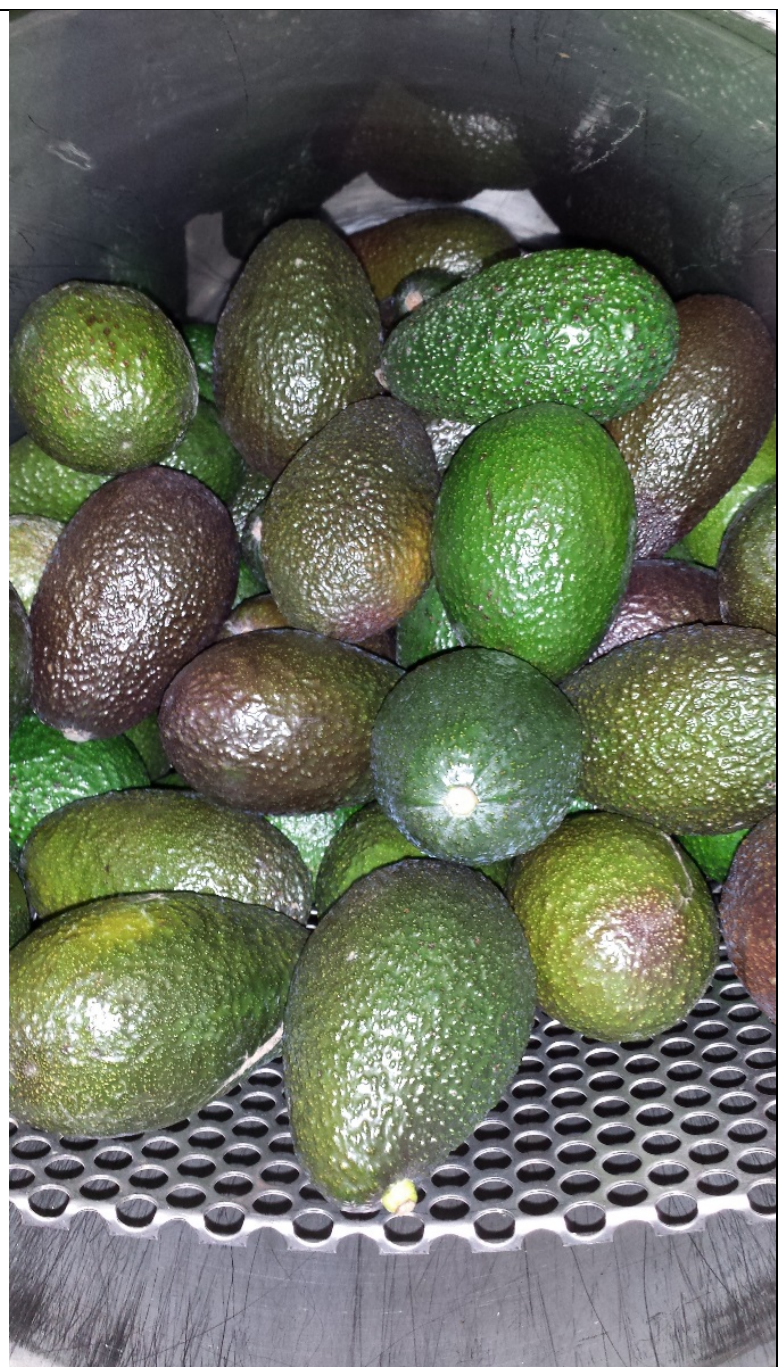

Fig. 13, avocado in 70 L container.

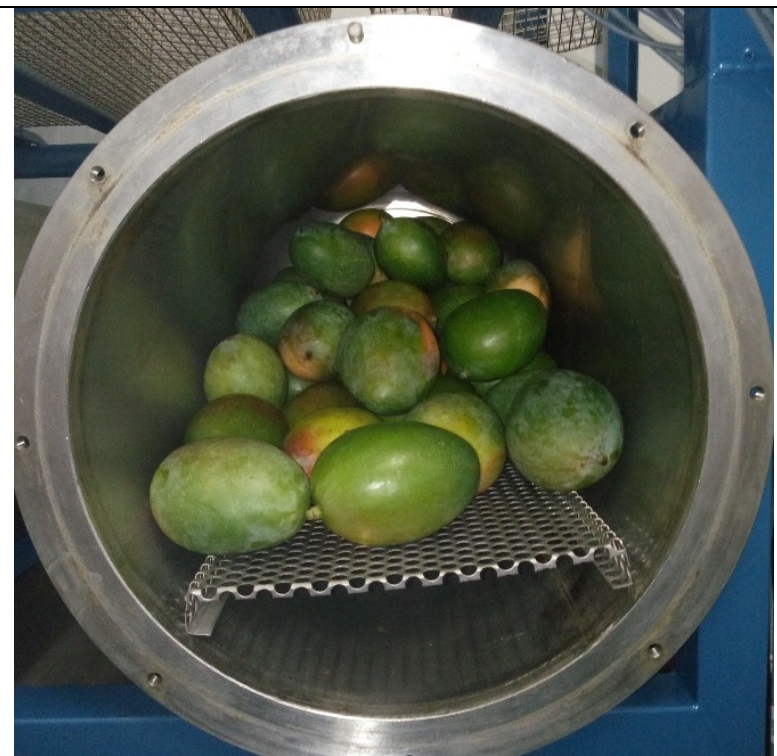

Fig. 14, mango in $70 \mathrm{~L}$ container. 


\subsection{Model calculations: effects of over pressure and moisture injection}

Daikin's CA unit actively injects a flow of treated air, with flow rate depending on operating condition (see Table 2). According to Daikin the CA unit inhales ambient air with its water vapour and expels all the water vapour into the container. Calculations are done to estimate the effect of that injected water on the container's water balance.

Due to the ongoing injection the container has an overpressure. That overpressure is measured, and calculations are done to estimate the effect of that over pressure on the ingress of ambient air. 


\section{$5 \quad$ Results}

\subsection{Test 1: air leakage}

Table 6 presents the air leakage test results.

Table 6, air leakage test results.

\begin{tabular}{|l|l|l|}
\hline measurement & Specification & Time from 490 till $245 \mathbf{P a}(\mathrm{m}: \mathbf{s s})$ \\
\hline 1 & With CA curtain at door-end & $4: 58$ \\
\hline 2 & Without CA curtain at door-end & $1: 24$ \\
\hline
\end{tabular}

\subsection{Test 2: generated nitrogen supply rate and purity}

Table 7 contains the measured flow rate and purity of the nitrogen supplied by the Daikin VPSA.

Table 7, measured nitrogen supply rate and purity.

\begin{tabular}{|l|l|l|l|l|}
\hline No. & $\begin{array}{l}\text { Date }[\mathbf{d d}-\mathbf{m m}- \\
\text { yyyy }]\end{array}$ & $\mathbf{T}_{\text {amb }}\left[{ }^{\circ} \mathbf{C}\right]$ & $\begin{array}{l}\text { Flow rate } \\
{[\mathbf{L} / \mathbf{m i n}]}\end{array}$ & $\mathbf{O}_{2}[\%]$ \\
\hline 1 & $29-9-2017$ & +46.5 & 16.60 & 5.08 \\
\hline 2 & $9-10-2017$ & -14.8 & 21.43 & 9.07 \\
\hline 3 & $9-10-2017$ & -16.2 & 20.46 & 7.32 \\
\hline 4 & $6-11-2017$ & 37.0 & 18.14 & 4.83 \\
\hline 5 & $7-11-2017$ & 27.4 & 16.13 & 4.80 \\
\hline 6 & $7-11-2017$ & 20.2 & 16.14 & 4.93 \\
\hline 7 & $8-11-2017$ & 10.3 & 15.82 & 5.18 \\
\hline 8 & $8-11-2017$ & 3.7 & 15.27 & 5.69 \\
\hline 9 & $9-11-2017$ & -8.0 & 16.0 & 6.14 \\
\hline 10 & $9-11-2017$ & -17.7 & 15.7 & 6.94 \\
\hline 11 & $10-11-2017$ & -18.1 & 15.0 & 6.96 \\
\hline
\end{tabular}

Note: Measurement 2 was collected approx. 1 hour after the CA unit was turned on.

Measurement 3 was collected four hours after the CA unit was turned on. According to Daikin in a cold environment the CA device first needs to run for three hours before it reaches its lowest possible $\mathrm{O}_{2}$ concentration. This renders measurement 2 invalid, but measurement 3 valid. Yet the elevated $\mathrm{O}_{2}$ concentration observed in measurement 2 and 3 was reason to initiate the measurement series no. 4 till 11. Measurement 4 till 11 were done without turning the CA unit off in between.

\subsection{Test 3: $\mathrm{CO}_{2}$ removal capacity}

Table 8 reports the results of the $\mathrm{CO}_{2}$ removal tests. In Table 8 the columns avg. $\mathrm{O}_{2}$ and avg. $\mathrm{CO}_{2}$ contain the time-averaged values recorded by the Daikin sensors during the period of interest. The column $\mathrm{CO}_{2, \text { ext }}$ contains the $\mathrm{CO}_{2}$ concentration, measured with a Dansensor, in the externally supplied gas flow $\phi_{\text {ext }}$, used to simulate respiration. The external gas supply with $\mathrm{O}_{2, \text { ext }}=$ 
$0 \%$ has a negative impact on the $\mathrm{O}_{2}$ balance of $\phi_{\text {ext }} \times 60 \times\left(\mathrm{O}_{2, \text { ext }}-\right.$ avg. $\left.\mathrm{O}_{2}\right) / 100$, simulating a respiration $m_{\text {prod }} \times r_{\mathrm{CO} 2}$ which would occur in real transports (see eqn. 1). The columns simulated resp. rate $\left[\mathrm{L} \mathrm{O}_{2} / \mathrm{h}\right]$ and simulated resp. rate $\left[\mathrm{L} \mathrm{CO}_{2} / \mathrm{h}\right]$ calculate respectively $\phi_{\text {ext }} \times 60 \times\left(\mathrm{O}_{2, \text { ext }}-\right.$ avg. $\left.\mathrm{O}_{2}\right) / 100$ and $\phi_{\text {ext }} \times 60 \times\left(\mathrm{CO}_{2, \text { ext }}-\right.$ avg. $\left.\mathrm{CO}_{2}\right) / 100$, the simulated respiratory effects of the external gas supply on respectively the $\mathrm{O}_{2}$ and $\mathrm{CO}_{2}$ balances. In a perfect test the numbers in these two columns are equal.

The last column in Table 8 concludes whether the controller can maintain $\mathrm{O}_{2}$ and $\mathrm{CO}_{2}$ in-range in this test condition. This is done using the in-range criterion specified by Daikin. Daikin deems control out of range if at least one of the following 3 conditions is true for more than 2 hours: $\left(\mathrm{CO}_{2}>\mathrm{CO}_{2, \text { set }}+1 \%\right)$ OR $\left(\mathrm{O}_{2}<\mathrm{O}_{2, \text { set }}-1 \%\right)$ OR $\left.\left(\mathrm{O}_{2}>\mathrm{O}_{2, \text { set }}+1 \%\right)\right)$.

Table 8 , steady state test results of $\mathrm{CO}_{2}$ removal capacity with $\mathrm{O}_{2, \text { set }}$ of $5 \%$ and $\mathrm{CO}_{2, \text { set }}$ of $3 \%$

\begin{tabular}{|c|c|c|c|c|c|c|c|c|c|c|}
\hline No. & $\begin{array}{l}\text { Date [dd- } \\
\text { mm-yyyy] }\end{array}$ & $\begin{array}{l}\text { durati } \\
\text { on [h] }\end{array}$ & $\begin{array}{l}\mathbf{T}_{\mathrm{amb}} \\
{\left[{ }^{\circ} \mathrm{C}\right]}\end{array}$ & $\begin{array}{l}\phi_{\text {ext }} \\
{[\mathrm{L} / \mathrm{min}]}\end{array}$ & $\begin{array}{l}\mathrm{CO}_{2, \mathrm{ext}} \\
{[\%]}\end{array}$ & \begin{tabular}{|l|} 
simulated \\
resp. rate [L \\
$\left.\mathrm{O}_{2} / \mathrm{h}\right]$ \\
\end{tabular} & $\begin{array}{l}\text { simulated resp. } \\
\text { rate }\left[\mathrm{L} \mathrm{CO}_{2} / \mathrm{h}\right]\end{array}$ & avg. $\mathrm{O}_{2}[\%]$ & avg. $\mathrm{CO}_{2}[\%]$ & in range \\
\hline 1 & 13-10-2017 & 4.0 & -14.0 & 0 & 0.0 & 0 & 0 & 9.8 & 0.0 & $\mathrm{NO}$ \\
\hline 2 & 13-10-2017 & 3.0 & -16.8 & 9 & 8.0 & 28 & 32 & 5.2 & 2.1 & YES \\
\hline 3 & 14-10-2017 & 10.0 & -17.4 & 19 & 7.9 & 60 & 48 & 5.3 & 3.7 & YES \\
\hline 4 & 14-10-2017 & 2.0 & -17.3 & 37 & 8.9 & 109 & 100 & 4.9 & 4.4 & $\mathrm{NO}$ \\
\hline 5 & $17-10-2017$ & 4.0 & -17.7 & 28 & 8.2 & 87 & 67 & 5.2 & 4.2 & $\mathrm{NO}$ \\
\hline 6 & 19-10-2017 & 4.0 & 44.4 & 0 & 0.0 & 0 & 0 & 7.4 & 0.0 & $\mathrm{NO}$ \\
\hline 7 & $20-10-2017$ & 4.0 & 47.6 & 26 & 8.6 & 95 & 98 & 6.1 & 2.3 & $\mathrm{NO}$ \\
\hline 8 & 20-10-2017 & 4.0 & 48.1 & 24 & 7.7 & 86 & 78 & 6.0 & 2.3 & YES \\
\hline 9 & $21-10-2017$ & 15.5 & 47.3 & 24 & 7.5 & 85 & 71 & 5.9 & 2.6 & YES \\
\hline 10 & 22-10-2017 & 10.0 & 47.2 & 34.6 & 8.9 & 120 & 127 & 5.8 & 2.8 & YES \\
\hline 11 & $22-10-2017$ & 4.0 & 46.7 & 50.6 & 8.7 & 149 & 158 & 4.9 & 3.5 & YES \\
\hline 12 & $23-10-2017$ & 5.0 & 46.7 & 61.8 & 9.3 & 185 & 182 & 5.0 & 4.4 & $\mathrm{NO}$ \\
\hline 13 & 23-10-2017 & 4.0 & 46.9 & 54.9 & 9.2 & 152 & 168 & 4.6 & 4.1 & $\mathrm{NO}$ \\
\hline 14 & $24-10-2017$ & 4.0 & 47.2 & 52.5 & 9.2 & 148 & 164 & 4.7 & 4.0 & YES \\
\hline
\end{tabular}




\subsection{Test 4: pulldown rate of $\mathrm{O}_{2}$ concentration in active and passive systems}

Fig. 15 displays the curves of $\mathrm{O}_{2}$ and $\mathrm{CO}_{2}$ measurements recorded in both the active and the passive pulldown test. Data shown are data recorded by Daikin's unit sensors. During the tests the external supply flow rate and concentrations were checked approx. once per three days. Over and over again the measured external supply flow rate was between 5.5 and $5.9 \mathrm{~L} / \mathrm{min}$, with a $\mathrm{CO}_{2}$ concentration between 19.4 and $19.9 \%$.

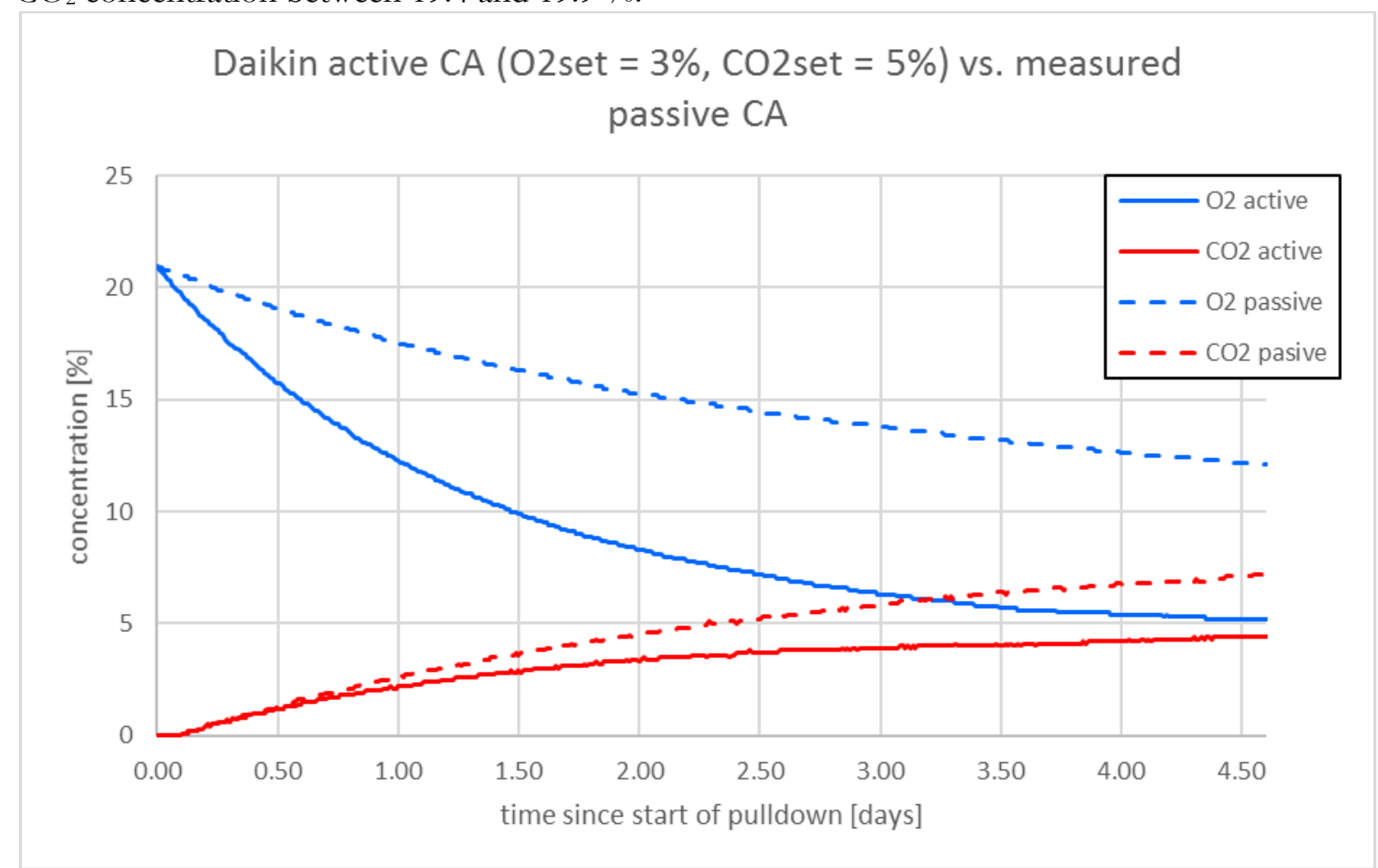

Fig. 15, active and passive pulldown test results of $\mathrm{CO}_{2}$ increase and $\mathrm{O}_{2}$ decrease.

\subsection{1 sensor accuracy}

During the passive pulldown test the $\mathrm{O}_{2}$ and $\mathrm{CO}_{2}$ concentrations were not only recorded by Daikin's $\mathrm{O}_{2}$ and $\mathrm{CO}_{2}$ sensors, but also with WFBR's Dansensor (Fig. 16), which was configured to sample the container atmosphere at a 10 minutes interval through the unit's sampling port for supply air (Fig. 17). The Dansensor is highly accurate, moreover right after completion of the passive test the Dansensor accuracy was confirmed by measuring two different gas samples with known composition (calibration gases), see Table 9. Fig. 18 presents the recordings collected during the passive pulldown. Fig. 19 presents the unit's $\mathrm{CO}_{2}$ recordings as a function of the Dansensor recordings. The blue line in Fig. 19 presents the same $\mathrm{CO}_{2}$ data as Fig. 18. Just the format is different. The blue line in Fig. 19 shows the $\mathrm{CO}_{2}$ readings of the unit's sensor as a function of the Dansensor: at the moment the Dansensor reading (horizontal axis) was e.g. 8.0\% the unit's sensor recorded $6.9 \%$ (vertical axis). The orange line represents the perfect situation: if the Dansensor reading (horizontal axis) is e.g. $8.0 \%$ then ideally the unit's sensor reading (vertical axis) is also $8.0 \%$. 


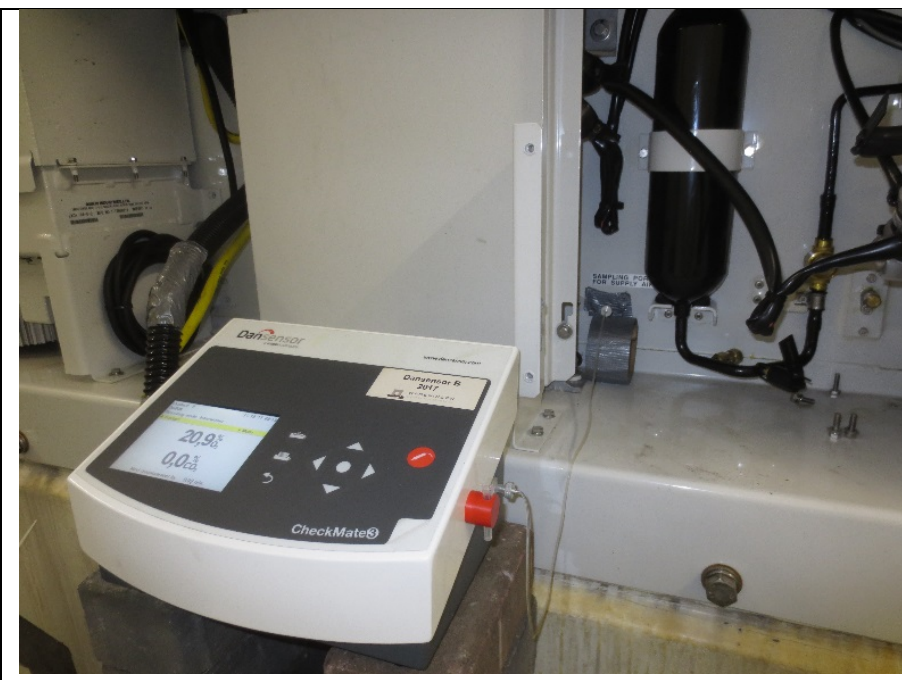

Fig. 16, Dansensor sampling through the unit's sampling port for supply air.

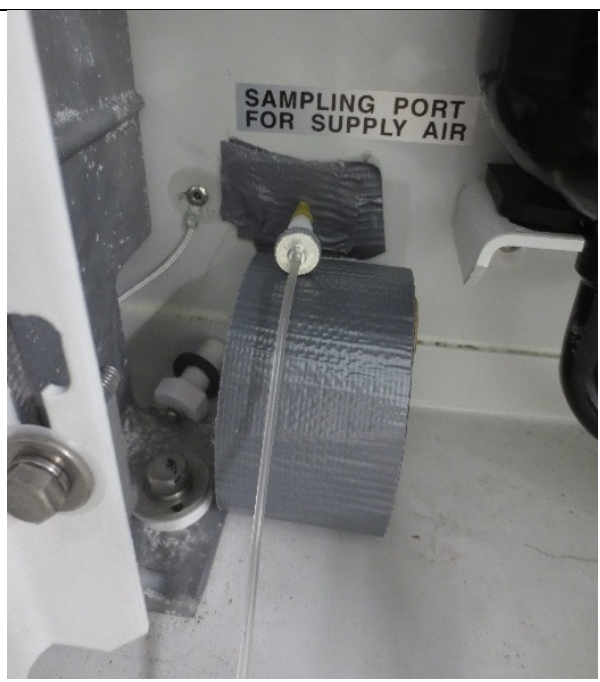

Fig. 17, Dansensor sampling through the unit's sampling port for supply air.

Table 9, readings in calibration gas right after completion of passive pulldown test.

\begin{tabular}{|l|l|l|}
\hline sample no. & calibration gas composition & Dansensor readings \\
\hline 1 & $\mathrm{O}_{2}=1.08 \%, \mathrm{CO}_{2}=2.00 \%$ & $\mathrm{O}_{2}=1.12 \%, \mathrm{CO}_{2}=2.1 \%$ \\
\hline 2 & $\mathrm{O}_{2}=21.0 \%, \mathrm{CO}_{2}=8.99 \%$ & $\mathrm{O}_{2}=21.0 \%, \mathrm{CO}_{2}=8.9 \%$ \\
\hline
\end{tabular}

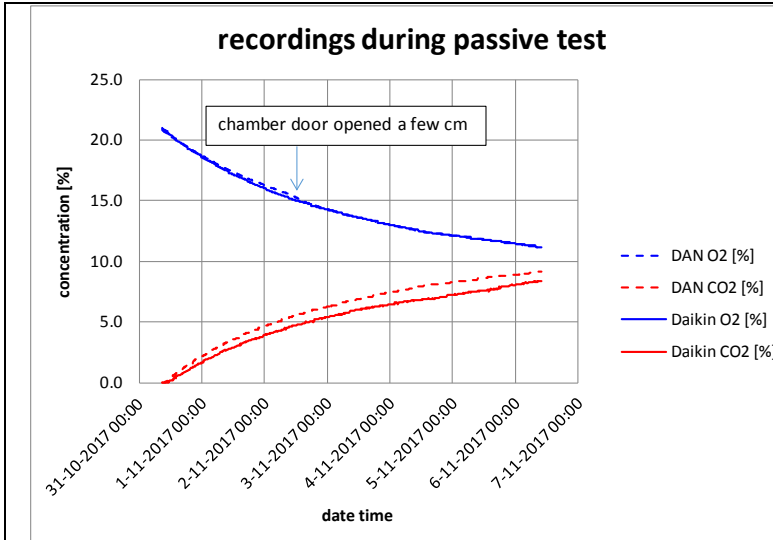

Fig. 18, recordings of unit's sensor and Dansensor during passive pulldown.

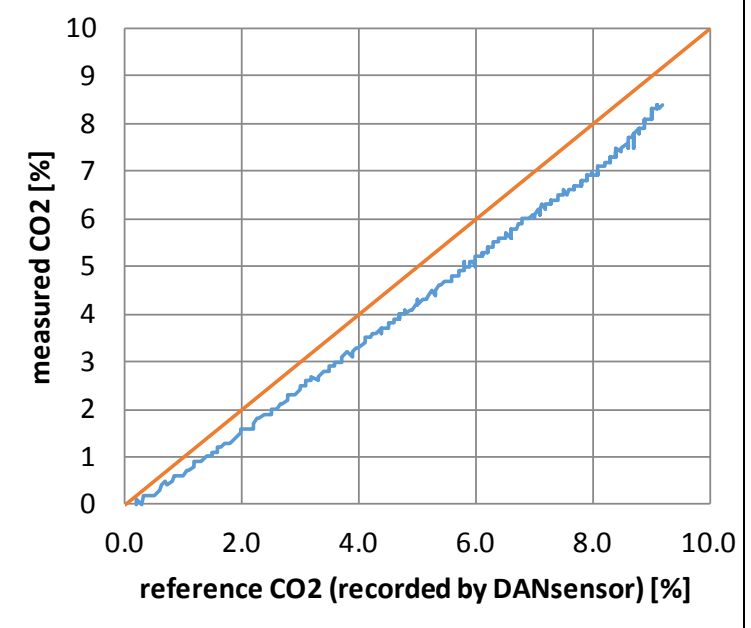

Fig. 19, unit's sensor vs. Dansensor during passive pulldown. 


\subsection{Test 5: Effect of CA on respiration rate}

The respiration rate results consist of the oxygen consumption rate $\left(\mathrm{mL} \mathrm{O}_{2} / \mathrm{kg}\right.$.hour $)$ and the carbon dioxide production rate $(\mathrm{mL} \mathrm{CO} / \mathrm{kg}$.hour) of products stored at one specific temperature and one specific atmosphere.

The results presented in Table 10 are the mean and standard deviation of the three containers and of the two measurement moments.

Table 10, respiration rate results measured for each product under control atmosphere (CA) and regular atmosphere ( $\mathrm{RA}) .(\mathrm{N}=6, \pm$ standard error)

\begin{tabular}{|c|c|c|c|}
\hline & & $\begin{array}{l}\mathrm{O}_{2} \text { consumption } \\
(\mathrm{mL} \mathrm{O} / \mathrm{kg} \text {.hour })\end{array}$ & $\begin{array}{c}\mathrm{CO}_{2} \text { production } \\
\text { (mL CO} 2 / \text { kg.hour) }\end{array}$ \\
\hline \multirow[t]{2}{*}{ Apple, cv. Cox Orange } & CA & $1.68 \pm 0.08$ & $1.53 \pm 0.03$ \\
\hline & RA & $2.09 \pm 0.05$ & $1.89 \pm 0.02$ \\
\hline \multirow{2}{*}{$\begin{array}{l}\text { (green) Asparagus, cv. } \\
\text { unknown }\end{array}$} & CA & $7.50 \pm 0.38$ & $5.22 \pm 0.44$ \\
\hline & RA & $11.64 \pm 0.54$ & $6.50 \pm 0.36$ \\
\hline \multirow[t]{2}{*}{ Avocado, cv. Hass } & CA & $5.78 \pm 0.15$ & $4.55 \pm 0.30$ \\
\hline & RA & $14.36 \pm 0.31$ & $8.10 \pm 0.23$ \\
\hline \multirow[t]{2}{*}{ Banana, cv. Cavendish } & CA & $2.52 \pm 0.08$ & $1.84 \pm 0.04$ \\
\hline & RA & $4.51 \pm 0.30$ & $3.29 \pm 0.17$ \\
\hline \multirow[t]{2}{*}{ Blueberry, cv. unknown } & CA & $4.12 \pm 0.18$ & $3.03 \pm 0.26$ \\
\hline & RA & $3.82 \pm 0.13$ & $2.94 \pm 0.06$ \\
\hline \multirow{2}{*}{$\begin{array}{l}\text { Iceberg lettuce, cv. } \\
\text { unknown }\end{array}$} & CA & $1.35 \pm 0.13$ & $1.04 \pm 0.02$ \\
\hline & RA & $1.83 \pm 0.03$ & $1.33 \pm 0.03$ \\
\hline \multirow[t]{2}{*}{ Mango, cv. Keitt } & CA & $5.53 \pm 0.03$ & $4.17 \pm 0.10$ \\
\hline & RA & $7.13 \pm 0.11$ & $5.13 \pm 0.14$ \\
\hline
\end{tabular}

\subsection{Model calculations: effects of over pressure and moisture injection}

\subsection{1 water vapour injection}

The table below calculates the amount of ambient water vapour injected in the container. It assumes ambient air of $30{ }^{\circ} \mathrm{C}$ and $100 \%$ relative humidity. According to the Mollier chart that air contains 26 (g water)/(kg air) (no. 1 in Table 11) and has a density of $1.13 \mathrm{~kg} / \mathrm{m}^{3}$ (no. 2 in Table 11). Assume the unit operates all the time in 5\%-mode (no. 3 in Table 11) during a 30 days trip (no. 4 in Table 11). Then the amount of water vapour injected over the complete trip is $12.7 \mathrm{~kg}$ (no. 5 in Table 11). 
Table 11, impact of injecting ambient moisture.

\begin{tabular}{|c|c|c|}
\hline No. & description & Value \\
\hline & CALCULATION INPUTS & \\
\hline 1. & Ambient water vapour content & 26 (g water)/(kg air) \\
\hline 2. & Air density & $1.13 \mathrm{~kg} / \mathrm{m}^{3}$ \\
\hline 3. & $\begin{array}{l}\text { CA unit's flow rate (assuming operation in 5\%-mode all the } \\
\text { time) }\end{array}$ & $10 \mathrm{~L} / \mathrm{min}$ \\
\hline 4. & duration & 30 days \\
\hline & CALCULATION OUTPUT & \\
\hline 5. & $\begin{array}{l}\text { Amount of water vapour injected during complete trip }(=\text { (no. } 1) \\
\times 1 / 1000 \times(\text { no. } 2) \times(\text { no. } 3) \times 1440 / 1000 \times(\text { no. } 4)\end{array}$ & $12.7 \mathrm{~kg}$ \\
\hline
\end{tabular}

\subsection{2 effect of over pressure on the ingress of ambient air}

During the tests the static air pressure difference between inside and outside the container was recorded. The internal air pressure sampling point is in the T-bar near the door-end. Table 12 summarizes the results. The negative pressure when only the unit is on (test 1) is explicable: a positive pressure between evap. fans and evaporator, ad a negative air pressure in the air flow's pathway from evaporator to evaporator fans.

Table 12, steady state pressure difference (inside - outside) measurements at $T_{a m b}=38$ ${ }^{\circ} \mathrm{C}$ and $\mathrm{T}_{\text {set }}=14.0^{\circ} \mathrm{C}$, fresh air exchange closed.

\begin{tabular}{|l|l|l|l|}
\hline No. & Period & Description of test condition & $\begin{array}{l}\text { Overpressure } \\
{[\mathbf{P a}]}\end{array}$ \\
\hline 1 & $\begin{array}{l}30-10-2017 \text { 18:30 } \\
31-10-2017 \text { 8:45 }\end{array}$ & unit ON, CA OFF & $-33 \mathrm{~Pa}$ \\
\hline 2 & $\begin{array}{l}31-10-2017 \text { 10:00 } \\
1-11-2017 \text { 14:00 }\end{array}$ & $\begin{array}{l}\text { unit ON, CA OFF, external gas supply rate } \\
5.6 \mathrm{~L} / \mathrm{min}\end{array}$ & $6 \mathrm{~Pa}$ \\
\hline 3 & $\begin{array}{l}29-10-2017 \text { 0:00 } \\
30-10-2017 \text { 0:00 }\end{array}$ & $\begin{array}{l}\text { unit ON, CA ON in 5\% mode, external } \\
\text { gas supply rate 5.6 L/min }\end{array}$ & $28 \mathrm{~Pa}$ \\
\hline
\end{tabular}




\section{Discussion}

\subsection{Test 1: air leakage}

Even without CA curtain the measured air leakage rate (Table 6) meets the norm set in the ISO1496-2 standard, which specifies that the pressure from 490 to $245 \mathrm{~Pa}$ shall take at least 1:05 m:ss.

The CA curtain installation at the door-end was improvised. Because the container was not fitted with a CA curtain rail, the curtain had to be clasped between door gaskets and door frame (Fig. 4). Yet, despite the improvised installation, the CA curtain at the door-end extends the pressure decay time by a factor three. Which means that the air tightness of the unit itself meets the described standard.

\subsection{Test 2: generated nitrogen supply rate and purity}

At $+45{ }^{\circ} \mathrm{C}$ the observed performance of the $\mathrm{CA}$ system outperforms the manufacturer specifications with an $\mathrm{O}_{2}$ concentration marginally higher than specified, but a flow rate distinctly greater than specified (Table 7).

At ambient temperatures below $+10{ }^{\circ} \mathrm{C}$ the observed performance of the $\mathrm{CA}$ system does not meet the manufacturer specifications. The measured $\mathrm{O}_{2}$ concentration rises till $7 \%$ at $-18{ }^{\circ} \mathrm{C}$, which is distinctly higher than the $5 \%$ specified by the manufacturer.

It is remarkable that the test can be done by running the CA unit in RA conditions, as illustrated by the presence of people in the container during the test (Fig. 3). In RA the 8\%-mode would give faster pulldown than the 5\%-mode. Just an improved control logic could increase the performance of the CA unit.

\subsection{Test 3: $\mathrm{CO}_{2}$ removal capacity}

Main purpose of the test is to assess the $\mathrm{CO}_{2}$ removal capacity at $\mathrm{O}_{2, \text { set }}=5 \%$ and $\mathrm{CO}_{2, \text { set }}=3 \%$. To put it differently: what is the maximum respiration rate at which the unit is able to maintain $\mathrm{O}_{2}$ at set point, while avoiding that $\mathrm{CO}_{2}$ exceeds set point. At $\mathrm{T}_{\mathrm{amb}}=-18{ }^{\circ} \mathrm{C}$ the unit fails at a $\mathrm{CO}_{2}$ production rate of $67 \mathrm{~L} / \mathrm{h}$ (measurement no. 5 in Table 8), while it succeeds at $48 \mathrm{~L} / \mathrm{h}$ (measurement no. 3 in Table 8). The limit is in between: $\pm 55\left(\mathrm{~L} \mathrm{CO}_{2}\right) / \mathrm{h}$. At $\mathrm{T}_{\text {amb }}=+47^{\circ} \mathrm{C}$ the limit value is $164\left(\mathrm{~L} \mathrm{CO}_{2}\right) / \mathrm{h}$ (measurement no. 14 in Table 8). The influence of $\mathrm{T}_{\text {amb }}$ was unexpected, but matches with the observed effect of $\mathrm{T}_{\mathrm{amb}}$ on the supplied $\mathrm{O}_{2}$ purity (Table 7). During testing there were quite some struggles with interpreting the intermediate results: in which mode did the unit operate when, and what exactly is the control logic? It was beyond the knowledge of the Daikin representatives involved to answer these questions. The Daikin design team was said to be able to answer these questions, but was somehow reluctant to share their knowledge. This made the testing difficult and did not help to rapidly achieve clear results. However, eventually clear results were achieved.

It was assessed that the unit's $\mathrm{CO}_{2}$ sensor has an offset. As can be seen in Fig. 19 Dakin's sensor measures $4.0 \% \mathrm{CO}_{2}$ while true $\mathrm{CO}_{2}$ is about $4.8 \%$. Consequentially the calculated simulated respiration rates $\left[\mathrm{L} \mathrm{CO}_{2} / \mathrm{h}\right]$ in Table 8 are up to $20 \%$ too optimistic. Hence it is safe to state that, 
in the tested condition, this unit's $\mathrm{CO}_{2}$ removal capacity is at least $\pm 44\left(\mathrm{~L} \mathrm{CO}_{2}\right) / \mathrm{h}$ at $-18{ }^{\circ} \mathrm{C}$ and $131\left(\mathrm{~L} \mathrm{CO}_{2}\right) / \mathrm{h}$ at $+47{ }^{\circ} \mathrm{C}$.

What is the unit's $\mathrm{CO}_{2}$ removal capacity at a different $\mathrm{CO}_{2}$ set point? The test was done at a relatively low $\mathrm{CO}_{2}$ set point of $3 \%$. It is to be expected that at $2 \mathrm{x}$ higher $\mathrm{CO}_{2}$ set point it takes a $2 \mathrm{x}$ higher respiration before the unit can no longer avoid $\mathrm{CO}_{2}>\mathrm{CO}_{2}$ set point.

By comparing the respiration rates measured in Table 10 it can be assessed if the unit's $\mathrm{CO}_{2}$ removal capacity suffices to maintain $\mathrm{CO}_{2}$ at set point. E.g. 20 tonnes of bananas in CA respire $20 \times 1.84=36.8\left(\mathrm{~L} \mathrm{CO}_{2}\right) / \mathrm{h}$ according to Table 10 . At $\mathrm{T}_{\mathrm{amb}}=+47^{\circ} \mathrm{C}$ the unit's $\mathrm{CO}_{2}$ removal capacity of $131\left(\mathrm{~L} \mathrm{CO}_{2}\right) / \mathrm{h}$ has a good over capacity, but at $\mathrm{T}_{\text {amb }}=-18^{\circ} \mathrm{C}$ the measured $44(\mathrm{~L}$ $\left.\mathrm{CO}_{2}\right) / \mathrm{h} \mathrm{CO}$ removal capacity is at the limit. In short, the unit's over capacity is limited esp. at lower ambient temperatures. Hence it is to be expected that in shipments with low $\mathrm{CO}_{2, \text { set }}$ in cold ambient the unit will struggle to avoid too high $\mathrm{CO}_{2}$.

The unit failed to keep $\mathrm{O}_{2}$ in range at $\mathrm{O}_{2}$ set point $5 \%$ when respiration rate was low (measurement no. 1, 6 and 7 in Table 8). This was observed both at $\mathrm{T}_{\text {amb }}=-20$ and $+50{ }^{\circ} \mathrm{C}$. This observation is worrying because the unit is supposed to supply $5 \% \mathrm{O}_{2}$ continuously and, in view of the excellent air tightness (measurement 1 in Table 6), air leakage rate should be low. In CA control at any price avoid prolonged periods with $\mathrm{CO}_{2}>\mathrm{CO}_{2 \text {,set }}$ or $\mathrm{O}_{2}<\mathrm{O}_{2 \text {,set. }}$. Unfortunately that's not what the current control does. See e.g. Fig. 20 which contains data collected by Daikin's controller during measurement no. 12. It illustrates a period where the unit is still changing modes to keep $\mathrm{O}_{2}$ around set point, while it records $\mathrm{CO}_{2}>\mathrm{CO}_{2, \text { set. }}$. Apparently the unit does not do all it can to avoid prolonged periods with $\mathrm{CO}_{2}>\mathrm{CO}_{2 \text {,set. }}$ One would expect the unit to run in ventilation mode $100 \%$ of the time before it allows $\mathrm{CO}_{2}$ to rise. This should be changed. 


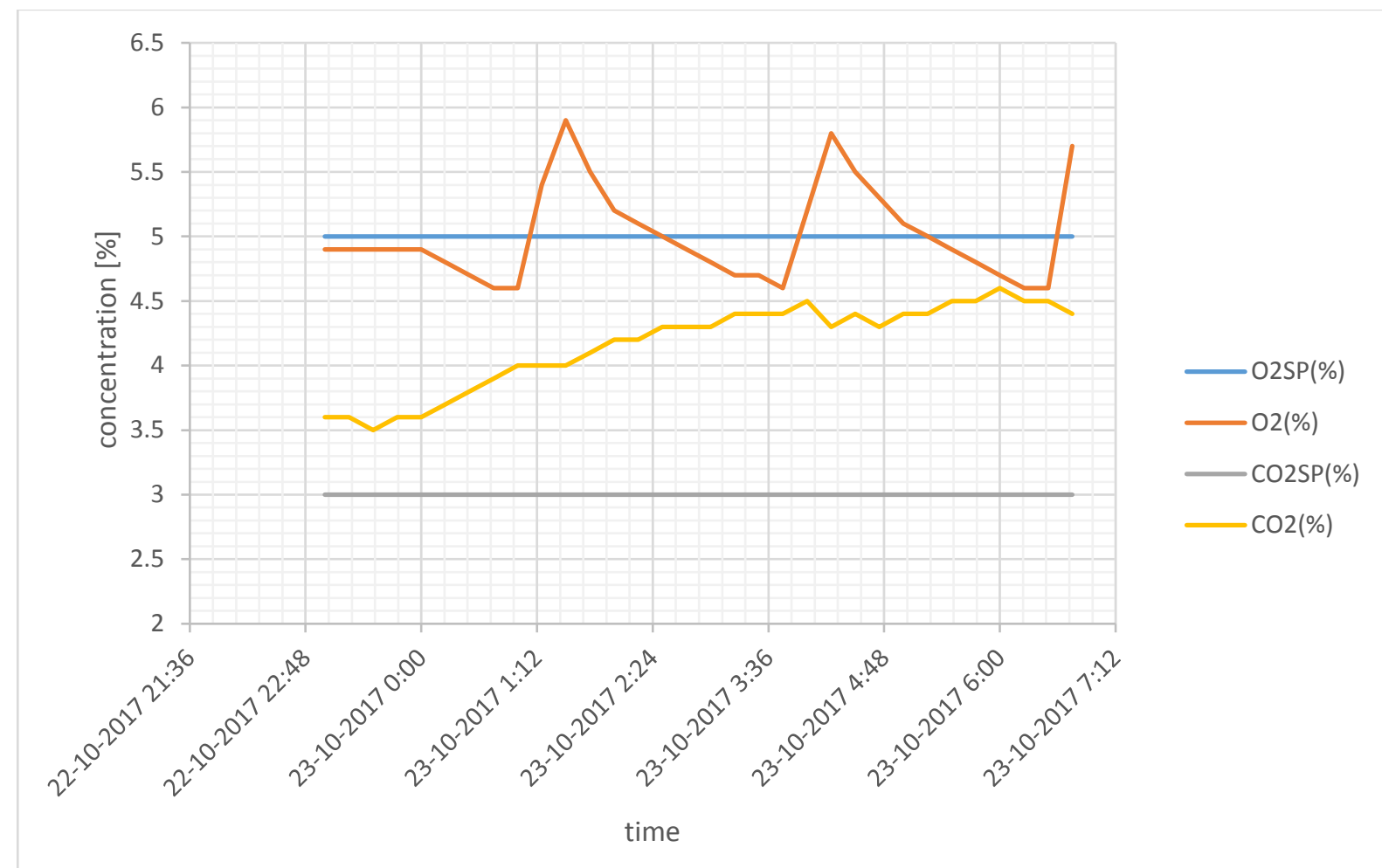

Fig. 20, $\mathrm{O}_{2}$ and $\mathrm{CO}_{2}$ concentrations recorded by Daikin's controller during measurement 12 (Table 8).

Fig. 21 shows the gas concentrations recorded by Daikin's controller after external gas supply stopped at 15-10-2017 10:45. It is remarkable that there is no sharp bend in the pace of $\mathrm{CO}_{2}$ decrease. One would expect that the unit initially runs in the $8 \%$-mode or ventilation mode to decrease $\mathrm{CO}_{2}$, and then around 14:24 stops or transitions to 5\%-mode as the need to reduce $\mathrm{CO}_{2}$ no longer exists. Apparently this does not happen. This looks like another aspect where the CA unit's control could be improved.

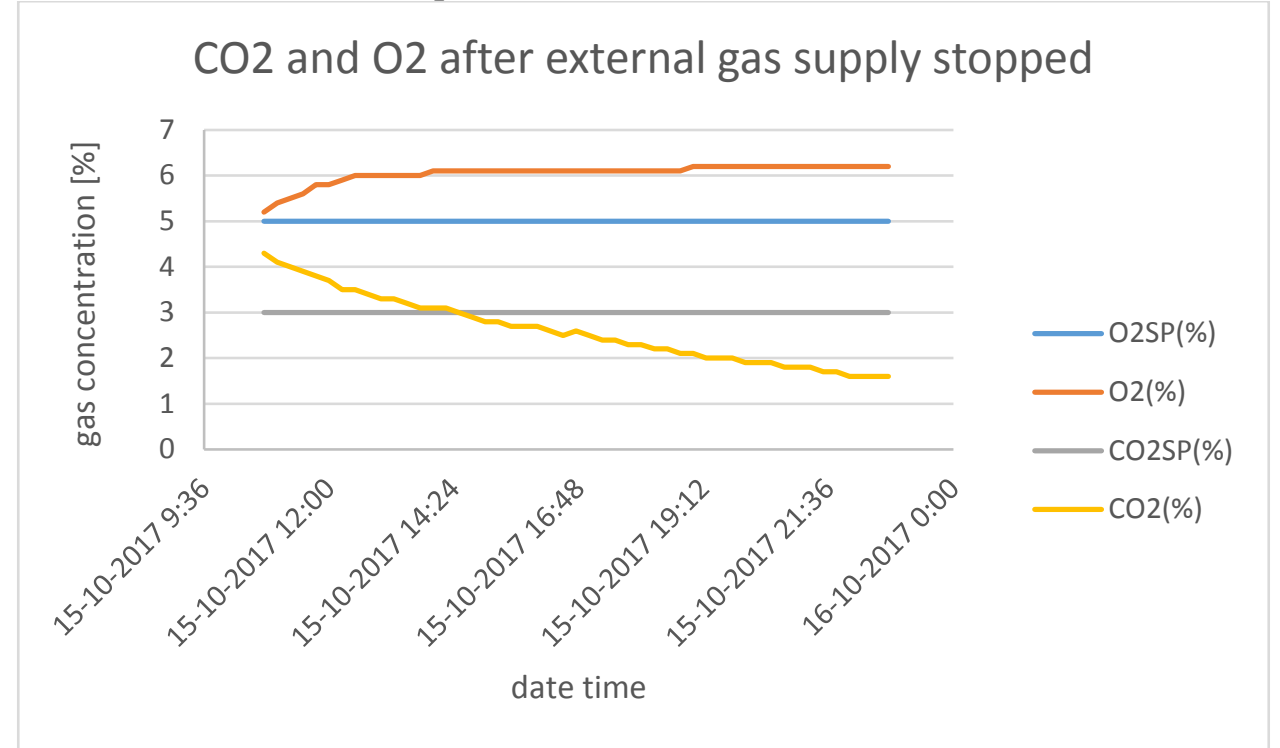

Fig. 21, gas concentrations after external flushing stopped at 10:45. 


\subsection{Test 4: pulldown rate of $\mathrm{O}_{2}$ concentration in active and passive systems}

At the end of the passive system test one of the three balloons was found flat (Fig. 23). Visual inspection learnt that the balloon's valve had opened. Most likely this happened before start of the pulldown test because:

- probably a valve opens when the balloon is handled, i.e. just prior to closing the container doors.

- The container doors were closed 15 hours prior to the pulldown test start.

- The $\mathrm{O}_{2}$ and $\mathrm{CO}_{2}$ pulldown show a natural curve and not the irregular pattern to be expected when halfway during the test the balloon empties its RA content in the container air.

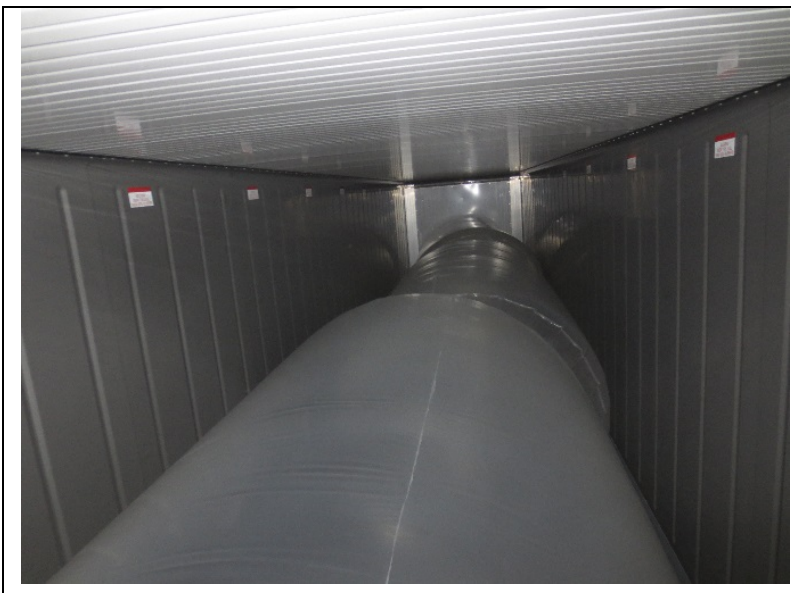

Fig. 22, three balloons of $10 \mathrm{~m}^{3}$ each, observed at start and end of active system test.

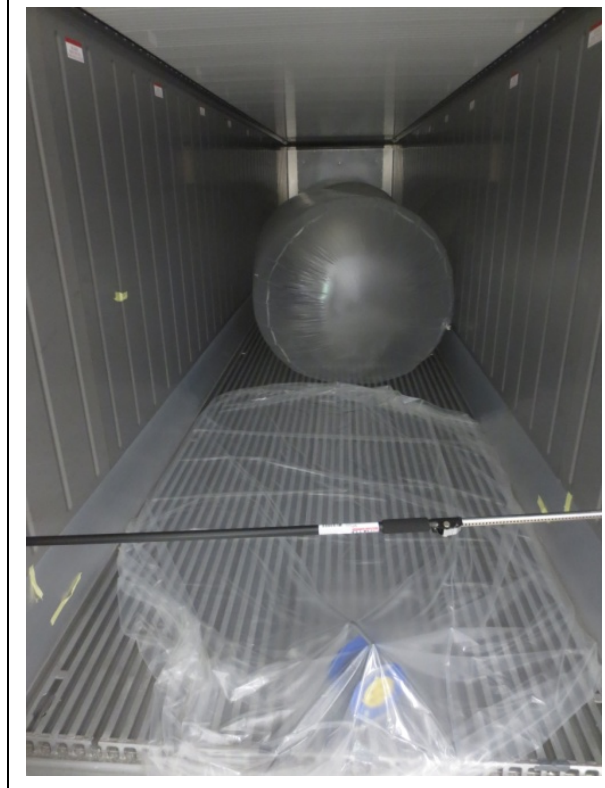

Fig. 23, two balloons of $10 \mathrm{~m}^{3}$ each, observed at end of passive system test.

Hence it is safe to assume that the complete passive system test has been done with two instead of three balloons. How does that impact the rate of $\mathrm{O}_{2}$ decrease and $\mathrm{CO}_{2}$ increase? As mentioned in section $4.4 \mathrm{~V}_{\text {air }}$ in equations 1 and 2 affects the rate of pulldown. In an empty $40 \mathrm{ft} \mathrm{HC}$ container $\mathrm{V}_{\text {air }}=\mathrm{L} \times \mathrm{B} \times \mathrm{H}=11.59 \times 2.29 \times 2.55=68 \mathrm{~m}^{3}$. In a container filled with 3 balloons of $10 \mathrm{~m}^{3}$ each $\mathrm{V}_{\text {air }}=38 \mathrm{~m}^{3}$. In a container filled with 2 balloons of $10 \mathrm{~m}^{3}$ each $\mathrm{V}_{\text {air }}=48 \mathrm{~m}^{3}$. When Vair increases from 38 to $48 \mathrm{~m}^{3}$ that's an increase of $\pm 25 \%$, also causing a $25 \%$ increase in the time constant of equations 1 and 2 . Hence a good estimate of the passive system's response in case of three balloons is achieved by simply dividing the time vector of the passive test results in Fig. 15 by 1.25. Fig. 24 presents the corrected data. 


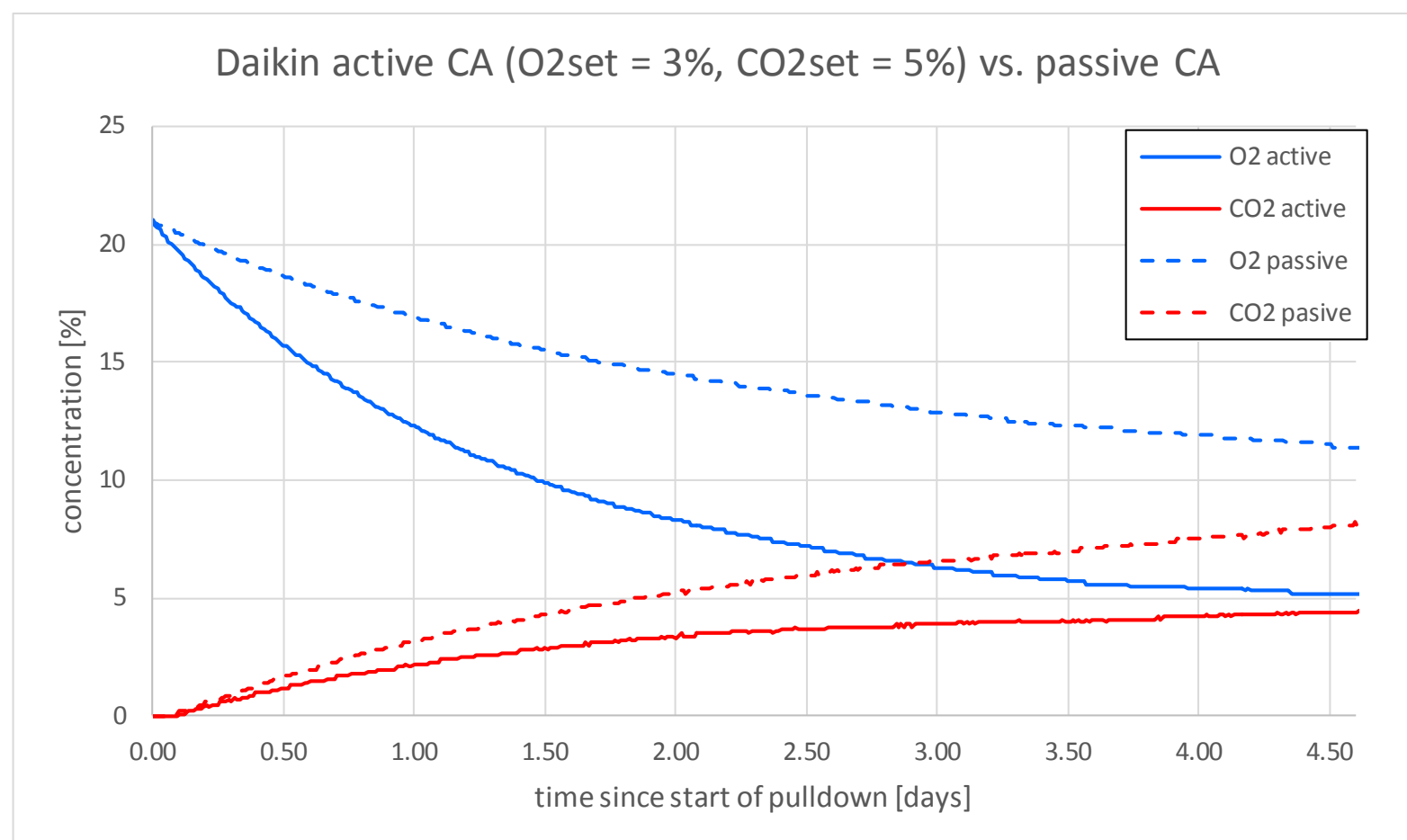

Fig. 24, active and passive pulldown test results (after correction of passive results for defalted balloon).

As Fig. 24 demonstrates the $\mathrm{O}_{2}$ pulldown of the active system is distinctly faster than the passive pulldown. After 4 days the active system has reduced $\mathrm{O}_{2}$ till approx. $5.5 \%$, while in the passive system $\mathrm{O}_{2}$ is than twice as high. Moreover only in the passive system $\mathrm{CO}_{2}$ has then risen to levels where it may well cause disorders to many species of fruit.

\subsection{1 sensor accuracy}

The unit's $\mathrm{O}_{2}$ sensor readings are perfect. Fig. 18 reveals a marginal deviation on 2-11-2017. This deviation is due to an error in the Dansensor. The Dansensor compares the $\mathrm{O}_{2}$ content in its sample (Fig. 17) to the $\mathrm{O}_{2}$ content in the air surrounding the device. During the test the container is continuously flushed with approx. $80 \% \mathrm{~N}_{2}$ and $20 \% \mathrm{CO}_{2}$. Of course the container's interior atmosphere leaks into the climate chamber. When the climate chamber is not vented that depresses the $\mathrm{O}_{2}$ concentration in the chamber. On 2-11-2017 that process was observed, and the chamber door was opened a few $\mathrm{cm}$ to vent the chamber with ambient air. That was enough to eradicate the Dansensor's deviation in the $\mathrm{O}_{2}$ recordings.

The unit's $\mathrm{CO}_{2}$ recording is worrying. The sensor records up to approx. $1 \%$ less than the true $\mathrm{CO}_{2}$ concentration (Fig. 19). Some of that error already exists at $0 \% \mathrm{CO}_{2}$. It is actually also visible during the first 0.2 days in Fig. 15: while the unit's measured $\mathrm{O}_{2}$ concentration decreases the measured $\mathrm{CO}_{2}$ concentration stays $0 \%$, also in the passive system test. This is physically inexplicable. In the CA-test (PTI menu) at least the error at $0 \% \mathrm{CO}_{2}$ should be detectable. Yet the unit passed the CA-test on 6-11-2017, right after termination of the passive pulldown test. Not only the sensor fault, but also the failure to detect it is worrying. $\mathrm{CO}_{2} 1 \%$ higher than intended is worse than $1 \%$ lower than intended, hence a unit sensor measuring $1 \%$ too low is 
worse than a sensor measuring $1 \%$ too high. This is a brand new unit. Sensor offsets tend to increase over time. Is this one unit an unfortunate case, or a bad omen for reliability of Daikin $\mathrm{CO}_{2}$ sensors in general?

\subsection{Test 5: Effect of CA on respiration rate}

With exception of the blueberry, the oxygen consumption and the carbon dioxide production of the products were slowed down by the control atmosphere conditions (Table 10).

The blueberry results contradict with the expectation. The measurement was made at the end of the North-European production season. Berries are then more active (higher respiration rate) and more subject to fungal infection. Fungi development was observed on both atmosphere conditions. This observation may have affected the results. The results do correspond with Beaudry (1993), who reported that when oxygen content was within the range of 4 to $8 \%$, oxygen consumption increased slightly when $\mathrm{CO}_{2}$ increased.

Which products benefit most from CA? In principle those products whose respiration rate reduces heavily by CA. But there are nuances. For example blueberries will clearly not benefit from reduced respiration rate, but it may still benefit from the antifungal properties of high $\mathrm{CO}_{2}$. Lettuce has a very low respiration rate, even in RA. Most likely other factors, like e.g. shrivel, limit storage life and not so much respiration rate. However the CA conditions may beneficially suppress the development of russet spotting (brown discoloration on the leave nerves) (Kader, 2002).

For all other commodities in Table 10 the CA conditions reduce the respiration rate significantly. Reduced respiration is often associated with a lower ethylene production, a lower softening rate and a slowdown of other biochemical and physiological changes. This may extend shelf life. It is to be expected that the more the respiration rate is reduced the more the product benefits from CA. Among the seven fruits and vegetables tested (Table 10) the respiration rate of avocado is strongest affected by CA. Also the respiration rates of green asparagus, banana and mango respond well to CA.

\subsection{Model calculations: effects of over pressure and water vapour injection}

\subsection{1 water vapour injection}

The calculation in Table 11 is based on extreme assumptions: usually the CA unit will not operate $100 \%$ of the time, ambient temperature will be lower than $30{ }^{\circ} \mathrm{C}$ and relative humidity less than $100 \%$. Even under the applied extreme assumptions the water vapour injection over a complete trip is only $12.7 \mathrm{~kg}$. Compared to a typical 20 tonnes load that is approx. $0.06 \%$ of the load weight. The possible positive effect on weight loss during a trip will be negligible.

Also the possible negative effect in terms of causing wet cartons upon arrival will be very hard to assess. Let's assume $0.5 \%$ evaporative weight loss during a trip. That is 20 (tonnes) $* 1000$ $(\mathrm{kg} /$ tonne $) * 0.5 / 100(\%)=100 \mathrm{~kg}$ of evaporated water which needs to find its way to the evaporator. That's again much more than the $12.7 \mathrm{~kg}$ injected by the CA unit. In short, the CA unit's effect on the container's water balance is negligible. 


\subsection{2 effect of over pressure on the ingress of ambient air}

External gas supply + CA running in 5\% mode (measurement no. 3 in Table 12) elevates the static overpressure in the T-bar at the door-end from -33 to $+28 \mathrm{~Pa}$. External gas supply alone yields $+6 \mathrm{~Pa}$ (measurement no. 2 in Table 12). Let's therefore credit the CA system with a $22 \mathrm{~Pa}$ pressure increase from +6 to $+28 \mathrm{~Pa} .22 \mathrm{~Pa}$ is just not enough to compensate for the $-33 \mathrm{~Pa}$ under pressure (measurement no.1).

In a sheltered environment the extra $22 \mathrm{~Pa}$ nearly annuls all ingress of ambient air. Reefers tend to operate in windy locations on vessels and terminals. In a windy environment the static pressure around the container varies over time and place and the positive impact of the internal overpressure decreases. The dynamic pressure of wind is given by

$$
P_{d y n}=\frac{1}{2} * \rho * v^{2}
$$

Where $\rho$ is the density of air, approx. $1.2 \mathrm{~kg} / \mathrm{m}^{3}$, and $\mathrm{v}$ the air velocity in $\mathrm{m} / \mathrm{s}$. Table 13 shows the dynamic pressure at wind force 4 and 10 .

Table 13, dynamic pressure of air as a function of wind velocity.

\begin{tabular}{|l|l|l|}
\hline Wind force (Beaufort) & Wind velocity [km/h] & Dynamic pressure [Pa] \\
\hline 4 & 25 & 30 \\
\hline 10 & 100 & 460 \\
\hline
\end{tabular}

When wind hits the container wall perpendicularly and all its dynamic pressure is converted into static pressure then at wind force 4 the CA unit's $22 \mathrm{~Pa}$ extra pressure is already less than the 30 $\mathrm{Pa}$ pressure built up against the container wall, and at wind force 10 the wind-induced overpressure dwarfs the CA system's $22 \mathrm{~Pa}$. Hence in calm weather the CA system's overpressure largely suppresses the ingress of ambient air, but in more windy weather that positive effect rapidly diminishes. 


\section{Conclusions}

1. The container air tightness surpasses the ISO1496-2 standard. Part of the air leakage occurs at the door-end. Hence the unit's air tightness amply surpasses the ISO1496-2 standard.

2. At ambient temperatures above $+10{ }^{\circ} \mathrm{C}$ the $\mathrm{CA}$ system is able to generate approx. 16 $\mathrm{L} / \mathrm{min}$ of air with approx. $5 \% \mathrm{O}_{2}$. This purity is as specified by the manufacturer, while the flow rate largely exceeds the manufacturer spec. At lower ambient temperature the $\mathrm{O}_{2}$ concentration no longer meets the manufacturer specifications.

3. At $\mathrm{T}_{\text {set }}=+6{ }^{\circ} \mathrm{C}, \mathrm{O}_{2, \text { set }}=5 \%$ and $\mathrm{CO}_{2, \text { set }}=3 \%$ the unit's $\mathrm{CO}_{2}$ removal capacity is at least $44\left(\mathrm{~L} \mathrm{CO}_{2}\right) / \mathrm{h}$ at $-18{ }^{\circ} \mathrm{C}$ and $131\left(\mathrm{~L} \mathrm{CO}_{2}\right) / \mathrm{h}$ at $+47{ }^{\circ} \mathrm{C}$. It is to be expected that in shipments with low $\mathrm{CO}_{2, \text { set }}$ in cold ambient air the unit will struggle to avoid too high $\mathrm{CO}_{2}$.

4. The active system significantly accelerates the rate of $\mathrm{O}_{2}$ pulldown. In this assessment the active system reduced $\mathrm{O}_{2}$ till approx. $5.5 \%$ in 4 days, while in the passive system $\mathrm{O}_{2}$ was still twice as high after four days.

5. The tested CA conditions largely reduce the respiration rate of the seven tested fruits and vegetables, esp. avocado, green asparagus, banana and mango respond well to the tested CA conditions.

6. The unit's $\mathrm{CO}_{2}$ sensor reports values up to $1 \%$ less than the true $\mathrm{CO}_{2}$ concentration, and this fault is not detected in the unit's CA pre-trip inspection.

7. The CA unit's effect on the container's water balance is negligible.

8. In calm weather the CA system's overpressure largely suppresses the ingress of ambient air, but in more windy weather that positive effect largely diminishes. 


\section{$8 \quad$ Recommendations}

1. Revise the CA unit's control logic. Involve WFBR in improving the control specifications, and later on in testing to verify the correct implementation.

2. Test conditions were found in which $\mathrm{O}_{2}$ was regulated around set point, while $\mathrm{CO}_{2}>$ $\mathrm{CO}_{2, \text { set }}$ (Fig. 20). This is the wrong priority and a recipe for damaging the carried product. Change the control logic such that prolonged periods with $\mathrm{CO}_{2}>\mathrm{CO}_{2, \text { set }}$ or $\mathrm{O}_{2}<\mathrm{O}_{2, \text { set }}$ are avoided.

3. Mind the gas sensor accuracy, and verifying the accuracies in PTI (CA-tests).

4. Many products will especially benefit from $\mathrm{O}_{2}$ less than $5 \%$. The $5 \%$-mode and $8 \%$-mode are arbitrary choices. In fact the CA unit could probably also have a $2 \%$ mode, although the flow rate would then be very low. Make a control strategy in which the unit will supply a flow with lower than $5 \% \mathrm{O}_{2}$ in situations where that is beneficial.

5. Daikin wants to claim that it's unit removes ethylene by the continuous supply of a gas flow with low $\mathrm{O}_{2}$. Not unreasonable, but it may happen that the unit falls in respiration mode for prolonged periods. Therefore consider removing the respiration mode in which the VPSA system is switched off. 


\section{References}

Beaudry R.M. (1993). Effect of carbon dioxide partial pressure on blueberry fruit respiration and respiratory quotient. PBT, Vol. 3 (3): 249-258

Kader A.A. (2002). Modified atmospheres during transport and storage. In: University of

California Agriculture and Natural Resources $3^{\text {rd }}$ ed. Postharvest technology of horticultural crops, pp. 135-144. 


\section{Acknowledgements}

We are grateful to Daikin Industries Ltd., represented by Harm Louwen and Kenji Takata, for the pleasant cooperation throughout the project. 


\section{Appendix 1, nomenclature}

Table 14, nomenclature

\begin{tabular}{|l|l|l|}
\hline symbol & description & unit \\
\hline$\phi_{\text {ext }}$ & $\begin{array}{l}\text { supply flow rate of external gas mixture, used in tests to simulate } \\
\text { respiration }\end{array}$ & $\mathrm{L} / \mathrm{min}$ \\
\hline$\phi_{\mathrm{vpsa}}$ & VPSA supply air flow rate & $\mathrm{L} / \mathrm{min}$ \\
\hline $\mathrm{CO}_{2, \mathrm{xxt}}$ & $\mathrm{CO}_{2}$ in externally supplied gas mixture simulating respiration & $\%$ \\
\hline $\mathrm{O}_{2, \mathrm{ext}}$ & $\mathrm{O}_{2}$ in externally supplied gas mixture simulating respiration & $\%$ \\
\hline $\mathrm{CO}_{2, \mathrm{vpsa}}$ & $\mathrm{CO}_{2}$ supplied by VPSA & $\%$ \\
\hline $\mathrm{O}_{2, \mathrm{vpsa}}$ & $\mathrm{O}_{2}$ supplied by VPSA & $\%$ \\
\hline $\mathrm{CO}_{2}$ & $\mathrm{CO}_{2}$ in container & $\%$ \\
\hline $\mathrm{O}_{2}$ & $\mathrm{O}_{2}$ in container & $\%$ \\
\hline $\mathrm{r}_{\mathrm{CO} 2}$ & Respiratory CO $\mathrm{C}_{2}$ production rate & {$\left[\mathrm{L.tonne} \mathrm{e}^{-1} \cdot \mathrm{h}^{-1}\right]$} \\
\hline $\mathrm{t}$ & time & $\mathrm{h}$ \\
\hline $\mathrm{m}_{\text {prod }}$ & Amount of produce in container & tonne \\
\hline $\mathrm{V}_{\text {air }}$ & Air volume in container & $\mathrm{m}^{3}$ \\
\hline & & \\
\hline
\end{tabular}




\section{Appendix 2, test log}

Table 15, test log.

\begin{tabular}{|l|l|}
\hline When & Description of activity \\
\hline $15-9-2017 \sim 3-10-2017$ & Effect of CA on respiration rate measured \\
\hline $27-9-2017$ & Container arrives \\
\hline $28-9-2017$ & Air leakage tested \\
\hline $29-9-2017$ & $\begin{array}{l}\text { Generated nitrogen flow rate and purity measured at }+50{ }^{\circ} \mathrm{C} \\
\text { (test } 2)\end{array}$ \\
\hline $30-9-2017 \sim 8-10-2017$ & Lost to failed tests and idling \\
\hline $9-10-2017$ & $\begin{array}{l}\text { Generated nitrogen flow rate and purity measured at }-20{ }^{\circ} \mathrm{C} \text { (test } \\
\text { 2) }\end{array}$ \\
\hline $10-10-2017 \sim 11-10-2017$ & Daikin investigates its CA unit \\
\hline $12-10-2017 \sim 16-10-2017$ & Max. CO 2 removal capacity at $-20{ }^{\circ} \mathrm{C}($ test 3$)$ \\
\hline $17-10-2017 \sim 18-10-2017$ & Chamber temperature changed from $-20{ }^{\circ} \mathrm{C}$ to $+50{ }^{\circ} \mathrm{C}$ \\
\hline $19-10-2017 \sim 24-10-2017$ & Max. CO 2 removal capacity at $+50{ }^{\circ} \mathrm{C}$ (test 3) \\
\hline $25-10-2017 \sim 30-10-2017$ & $\mathrm{O}_{2}$ pulldown rate in active system (test 4$)$ \\
\hline $31-10-2017 \sim 6-11-2017$ & $\mathrm{O}_{2}$ pulldown rate in passive system (test 4$)$ \\
\hline $6-11-2017 \sim 10-11-2017$ & $\begin{array}{l}\text { Generated nitrogen flow rate and purity measured at a series of } \\
\left.\text { temperatures between }-20{ }^{\circ} \mathrm{C} \text { and }+38{ }^{\circ} \mathrm{C} \text { (test } 2\right)\end{array}$ \\
\hline $14-11-2017$ & Container departs \\
\hline
\end{tabular}

